\title{
Scenario-Based Comprehensive Assessment for Community Resilience Adapted to Fire Following an Earthquake, Implementing the Analytic Network Process and Preference Ranking Organization Method for Enriched Evaluation II Techniques
}

\author{
Zheng He ${ }^{1,2} \mathbb{D}^{\text {, Huihua Chen }}{ }^{1, *} \mathbb{C}$, Hongyan Yan ${ }^{2}$, Yang Yin ${ }^{1}$, Qi Qiu ${ }^{1}$ and Tingpeng Wang ${ }^{1}$ \\ 1 School of Civil Engineering, Central South University, Changsha 410075, China; he0814@csu.edu.cn (Z.H.); \\ yinyang@csu.edu.cn (Y.Y.); 174801042@csu.edu.cn (Q.Q.); wangtp@csu.edu.cn (T.W.) \\ 2 School of Engineering Management, Hunan University of Finance and Economics, Changsha 410205, China; \\ yanhongyan@hufe.edu.cn \\ * Correspondence: chh@csu.edu.cn
}

Citation: He, Z.; Chen, H.; Yan, H.; Yin, Y.; Qiu, Q.; Wang, T.

Scenario-Based Comprehensive

Assessment for Community

Resilience Adapted to Fire Following an Earthquake, Implementing the Analytic Network Process and Preference Ranking Organization Method for Enriched Evaluation II Techniques. Buildings 2021, 11, 523. https://doi.org/10.3390/ buildings11110523

Academic Editors: Tao Wang, Jian Zuo, Hanliang Fu and Zezhou Wu

Received: 8 October 2021

Accepted: 6 November 2021

Published: 7 November 2021

Publisher's Note: MDPI stays neutral with regard to jurisdictional claims in published maps and institutional affiliations.

Copyright: (c) 2021 by the authors. Licensee MDPI, Basel, Switzerland. This article is an open access article distributed under the terms and conditions of the Creative Commons Attribution (CC BY) license (https:// creativecommons.org/licenses/by/ $4.0 /)$

\begin{abstract}
Natural hazards bring significant influences on and socioeconomic loss to cities and communities. Historic events show that fire following earthquake (FFE) is the most influential uncertain disturbance on the urban infrastructure system. Under the FFE scenario, the concept of resilience is widely implemented to make up the shortcomings derived from the traditional disaster management methodology. Resilient cities and communities are required to improve the systemic performance in responding to the FFE. To fulfill these goals, measuring community resilience is an essential work for municipal policy makers. Therefore, this study conducted a comprehensive assessment on community resilience adapted to the FFE scenario. The systematic literature review (SLR) was employed to identify the indicators, and the analytic network process (ANP) technique was implemented to determine their weights. 20 indicators were extracted, and 4 communities that encountered FFE in China were selected for the empirical analysis. Thereafter, the preference ranking organization method for enriched evaluation (PROMETHEE) II technique was selected through using the multicriteria decision analysis (MCDA) methods selection framework to fulfill the comprehensive assessment. The results were discussed and demonstrated with graphical analysis for interactive aid (GAIA) technique. The findings revealed that the G Community won the highest score and had the strongest performance. However, $\mathrm{H}$ Community had the lowest score and the weakest performance. The proposed comprehensive methods could benefit the decision-makers and the policy executors achieving the community resilience adapted to the FFE scenario by improving the effective indicators.
\end{abstract}

Keywords: community resilience; fire following earthquake; comprehensive assessment; MCDA

\section{Introduction}

In the past decades, sustainable development goals in multiple domains have been proposed to address the changing and deteriorating environment for the survival and development of human beings [1-5]. However, as the carrier which could provide basic living services for human development, the cities are facing a series of challenges where natural hazards have the greatest influence and the most serious social and economic losses [6,7].

To settle this issue, improving the system performance of the cities when these natural hazards occur has drawn a climbing degree of attention [8-11]. There are a lot of research scholars and participants realize that the sustainable development goals of cities should be embedded into the concept of resilience [12-15]. Hence, exploring the performance of the communities, which are the essential unit of the cities, after disasters and measuring 
the capability of the communities when adapting to the disasters is vitally significant and imperative [16-18]. Achieving resilient cities and communities will benefit the sustainable development of the cities in the aspects of society, economy, and environment $[19,20]$.

Among the uncertain disturbances, earthquakes are the most destructive and influential disaster for the infrastructure in the city and community. A resilient community in an earthquake-prone area should be able to withstand a major earthquake event and recover quickly from the event such that the functionality of the community is restored within a reasonable time framework $[20,21]$. In the process of planning and designing resilient communities, it is necessary to consider potential cascading events that could follow the initial earthquake. Historic events show that fire ignitions may follow an earthquake, causing further damage to a system that has already suffered a shock [22-27]. Fire following earthquake (FFE) will bring huge social and economic losses to the urban system [28,29].

To tackle this issue, the concept of "resilience" is highlighted for its significant advantages compared with the traditional hazard management methodology. A large number of historical empirical data provide evidence that a resilient community is more likely to be less influenced than non-resilient communities and to recover from the disaster more rapidly when encountering the disturbances at the same level. In the past decade, community resilience has drawn increasing attention worldwide. Achieving resilience has become a crucial goal for the planning and managing the infrastructure construction, the community, and the city.

Hence, to actualize resilient communities, it is imperative to improve the capacity of the communities to adapt to FFE. During this process, measuring and assessing community resilience is essential work for researchers and policy makers. In spite of the large body of prior studies that have made some progress related to measuring the resilience of cities and urban communities, there are very limited scholars who pay attention to the comprehensive assessment indicators on community resilience under a fire post-earthquake scenario. Therefore, this study aims to investigate the indicators and propose effective evaluation methods to help the decision-makers and policy-producers to improve perception in constructing sustainable cities.

\section{Literature Review}

Prior studies have made great progress on the concept of hazard. For example, a large body of literature took hazards as various negative social consequences caused by external emergencies where the hazard source is natural, objective, and external, and the "relational chain" between the hazard source and the social result is discontinuous, interrupted, and static [30-33]. From the sociological perspective, Kendra et al. [34] defined a hazard as: "an event with time-space characteristics that causes threats and substantial losses to society or other branches of society, resulting in social structural disorder and interruption of the function of the basic survival support system of social members". Fuchs et al. [35-37] argued that hazard is functional or event-oriented. That is, a hazard can be regarded as an external, sudden, and instantaneous event that has a negative impact on society as a whole within a specific time and space. Similarly, Birkmann et al. [38] defined a hazard as an event that causes social chaos and material damage. Mazzorana et al. [39] used exceptions and breaks through conventions to describe the relationship between hazards and social order, believing that "hazards are the destruction of social conventions". Kappes et al. [40] believed that the criteria for defining hazards could be measured by whether society needs long-term recovery. Navarro et al. [41] believed that the hazard event first brings death or loss and then causes secondary social, political, and economic impacts. Janizadeh et al. [42] believed that sociology should study social changes in hazardous situations. Moreover, other geophysicists pay more attention to natural phenomena, such as earthquakes, tornadoes, and floods. The failure of the social, cultural system has caused the vulnerability of members of society in the face of external and internal threats. Based on this, Monge et al. [43] defined a hazard as "the result of the interaction between vulnerable people and extreme natural events". Berlemann et al. [44] emphasized: "a hazard can no 
longer be regarded as an emergency. The occurrence of a hazard is actually a manifestation of human vulnerability to environmental threats and extreme events". Kendra et al. [34] believed that hazards could not only be regarded as static events but also a dynamic social result. Therefore, the occurrence of hazards is not only a consequence of extreme events but also a result of vulnerability. Stritih et al. [45] regarded hazards as a kind of collective pressure and believed that most research on hazards focused on the "community level", and those hazard events should be classified and dealt with. It can be seen that the research on hazards has shifted from result-oriented hazard cognition to the investigation of hazard social factors from the perspective of the whole process, which has led to the rise in community hazard-related research based on the concepts of vulnerability and resilience.

For the infrastructure system of a city, when the degree of danger and destructive power from the hazards exceed the capacity of the urban infrastructure system, the hazard will develop into a disaster [46]. Earthquakes are often the most serious of the above hazards and are often without warning $[47,48]$. The level of earthquakes is generally divided into 12, from ultra-micro earthquakes to huge earthquakes [49]. Earthquake disasters can be divided into direct disasters and secondary disasters according to the degree of relevance and derivation of their impact on nature and society [50]. Direct disasters are ground vibrations and cracks [51-54]. There are three main manifestations of damage caused by rupture: First, the direct damage to buildings and engineering facilities, which is also an important cause of the loss of life and property $[55,56]$. The second is ground surface damage. Strong vibration will directly affect the ground surface, such as ground cracks, landslides, sand liquefaction, and ground subsidence [57-59]. The third is the tsunami caused by the disturbance of the water body caused by vibration. The secondary disasters of earthquakes are various catastrophic events caused by earthquake disasters, such as fires, mudslides, toxic gas leaks, plagues, etc. [60-62]. These disasters are often affected by economic and social conditions, and to a large extent, they will be more severe than direct disasters toward impact and loss [11,63,64]. In addition, with the development of the economy and society, the so-called "third disaster", such as the paralysis of information and communication, the loss of data and information, and the destruction of network systems, has also become an important aspect of earthquake disasters [65].

A resilient community in an earthquake-prone area should be able to withstand a major earthquake event and recover quickly from the event such that the functionality of the community is restored within a reasonable time frame [66]. Compared with the impacts exerted on the community by the earthquake, the events chain during the post-earthquake phase will bring a greater cascading effect. Historic events show that fire ignitions may follow the earthquake, causing further damage to a system that has already suffered a shock. Fire following the earthquake will bring huge social and economic losses to the urban system. When a fire following the earthquake breaks out in an urban community, residents and other people in the community may suffer burns, scalds, suffocation, jump off buildings, and other hazards [13,67]. High temperature and burning cause damage to buildings, structures, and infrastructure and cause losses to residents' properties and other community assets. The dense smoke produced by the fire affects the appearance of the building and causes environmental pollution [68-70]. In addition, the use of fire extinguishers, fire sprinklers, and firetruck fire extinguishing equipment will cause secondary damage to buildings and residents' properties [71]. Finally, news and media reports will reduce the brand, function, and cultural effects of the community. Old communities or poorly managed communities often have problems, such as the occupation of fire lanes, insufficient or ineffective firefighting facilities, and lack of safety education among residents, which further worsens the impact of fires.

Hence, considering the community resilience for the urban infrastructure in a fire following earthquake scenario is imperative and crucial [72-76]. In the past decades, prior studies have investigated community resilience from different perspectives. For instance, Tan [77] proposed an assessment method to measure community resilience by investigating policy factors. The study put forward that the current research lacks em- 
pirical validation and historic data toward proposed resilience assessment tools. Based on the risk perspective, Ji et al. [30] proposed the evaluation and decision-making plan of the reliability and stability of urban infrastructure. Their findings revealed that the distribution and intensity of risk greatly affect the anti-risk planning of the city's administrative area, thereby changing the resilience of the community. Moreover, other scholars, including Abdelhady et al. [78], Wang et al. [79], Her et al. [80], Gholizadeh [81], Nofal [82], Baca et al. [83], Chen and Ji [84], etc., conducted some regional studies using a small sample analysis method. Additionally, studies of resilience for different types of urban infrastructure in communities were implemented in a large body of literatures. For instance, the power distribution infrastructure systems by Kim et al. [85]. More prior studies focused on regional research of community resilience [86,87]. However, there is lack of a set of systematic indicator systems for assessing the community resilience. Hence, this study aims to make a comprehensive assessment on community post hazard-adapting resilience under the scenario of fire following earthquake.

The objectives of this study were as follows: (1) investigating indicators of community post-hazard-adapting resilience under fire post-earthquake scenario, (2) determining the weights of the indicators using ANP, (3) establishing the assessment model and selecting the studies community samples, (4) comparing and analyzing the assessment results.

The organization of the paper and the logic framework are as follows. Section 3 raises the methodology of this study. Section 4 implements the proposed methods through the empirical analysis of four communities in China, Section 5 lists the results and conducts the discussion, and Section 6 makes the conclusions.

\section{Research Methodology}

\subsection{Design of the Empirical Analysis}

Empirical analysis is a widely implemented method in a larger number of articles related to comprehensive assessment (e.g., He and Chen [88,89], Moghayedi et al. [90], Dang et al. [91], Olawumi and Chan [92], Yu et al. [93], etc.). The processes of empirical analysis include two parts. The first part is to conduct a semi-structured interview with the people in key roles in a community. The design of the semi-structured interview is to determine the final indicators after the first round of identification. The second part is to carry out the investigation adapting a scoring scale and to determine the weight of each indicator.

\subsection{Identification of the Indicators on Community Resilience Adapted to FFE Using SLR}

Due to the lack of identifying the key concepts of community resilience, research perspectives and dimensions, evaluation indicators and influencing factors, and then mixing them together, many previous studies have resulted in a number of negative effects for follow-up research. Therefore, this study used a systematic literature review (SLR) to extract the initial indicators on community resilience adapted to FFE. SLR is a method of scientifically summarizing and collating texts by avoiding errors in selecting the literature and reducing the subjective factors. We used "community", "resilience/resilient", "fire following earthquake", "urban/city" as the keywords to be searched in the databases of Web of Science, Scopus, and Google Scholar, and verified the content of the obtained articles in the search results. In addition, the search scope was limited to titles, abstracts, and keywords. The language of the articles was limited to English. The article source was limited to peer-review journals. The publication time was set between 2011 and 2021.

After the search processing, the screening process is another crucial step in completing the SLR. Hence, we conducted screening strategies to fulfill the task. The screening strategies included:

1. Duplicated screening. As an article may belong to multiple databases (for example, articles published by Elsevier may be indexed by Google Scholar), the elimination process needed to be repeated to ensure that there were no duplicate articles in the results. 
2. Title filtering. We carried out the title screening process by reviewing the titles to filter these articles that were obviously not related to the assessment indicators of community resilience adapted to FFE.

3. Abstract filtering. Implementing abstract filtering was to check whether the detailed objectives and conclusions of the selected literature were related to the SLR strategies. It was necessary to obtain related information from the abstract and delete the articles which did not include the related contents about community resilience adapted to FFE.

4. Full-text filtering. In this step, we downloaded and read the full text to ensure the availability of articles that met the above screening strategies.

5. Reference filtering. Reference filtering was used to collect the missing articles from the references cited in the above-selected articles, which can provide the supplements.

The flowchart of using SLR is presented in Figure 1. Through SLR analysis, the initial indicators set are obtained and presented in Table 1.

Table 1. Indicators on community resilience adapted to FFE.

\begin{tabular}{|c|c|c|c|}
\hline Number & Indicators & Criteria Tier & Source of Data \\
\hline $\mathrm{C} 1$ & Safety and health of residents & \multirow{8}{*}{ Management and resource } & [94-96] \\
\hline $\mathrm{C}_{2}$ & $\begin{array}{c}\text { Participation rate of } \\
\text { stakeholders }\end{array}$ & & {$[94,97]$} \\
\hline $\mathrm{C}_{3}$ & $\begin{array}{l}\text { Earthquake and fire } \\
\text { prevention knowledge }\end{array}$ & & {$[83,84,98-101]$} \\
\hline $\mathrm{C}_{4}$ & $\begin{array}{l}\text { Chaos following an } \\
\text { earthquake }\end{array}$ & & {$[58,86,102]$} \\
\hline $\mathrm{C}_{5}$ & $\begin{array}{l}\text { Response time of the } \\
\text { firefighters }\end{array}$ & & [103-106] \\
\hline $\mathrm{C}_{6}$ & External support & & {$[77,107-109]$} \\
\hline $\mathrm{C}_{7}$ & $\begin{array}{l}\text { Emergency management } \\
\text { capabilities }\end{array}$ & & {$[94,110]$} \\
\hline $\mathrm{C}_{8}$ & Resource reserve & & {$[30,111-113]$} \\
\hline $\mathrm{C}_{9}$ & $\begin{array}{l}\text { Anti-seismic and fire-proof } \\
\text { design of buildings }\end{array}$ & \multirow{7}{*}{ Design and financial support } & {$[79,114-122]$} \\
\hline $\mathrm{C}_{10}$ & Finances of the community & & [123-125] \\
\hline $\mathrm{C}_{11}$ & Communication systems & & {$[83,84,94,126-129]$} \\
\hline $\mathrm{C}_{12}$ & Transportation systems & & {$[3-5,130-132]$} \\
\hline $\mathrm{C}_{13}$ & Security systems & & {$[77,81,113,133]$} \\
\hline $\mathrm{C}_{14}$ & Firefighting systems & & {$[99-101,134]$} \\
\hline $\mathrm{C}_{15}$ & Gas supply systems & & {$[79,135-137]$} \\
\hline $\mathrm{C}_{16}$ & Water supply systems & \multirow{5}{*}{$\begin{array}{l}\text { The function of urban } \\
\text { infrastructure }\end{array}$} & {$[79,80,93,138-140]$} \\
\hline $\mathrm{C}_{17}$ & Electricity supply systems & & {$[97,135,141-144]$} \\
\hline $\mathrm{C}_{18}$ & Active fire control systems & & {$[93,145,146]$} \\
\hline $\mathrm{C}_{19}$ & Sewage systems & & {$[34,147,148]$} \\
\hline $\mathrm{C}_{20}$ & Waste treatment systems & & [149-152] \\
\hline
\end{tabular}

\subsection{Calculating the Weights of Indicators Using ANP}

The analytic network process method [153] is developed to a non-independent hierarchical structure and can more accurately describe the relationships between each element. In the ANP network structure, indicators and their sets can influence and depend on each other $[154,155]$. Using the ANP method, not only can the comprehensive weight of the element to the target be obtained, but also the degree of mutual influence between the elements can be calculated [156,157]. Using the ANP method, the indicators system to be studied was divided into two parts, namely the control layer and the network layer. The control layer included goals and decision-making criteria. All decision-making criteria were independent of each other and were only governed by target indicators. The weight calculation method of the criteria and sub-criteria in the control layer was the same as the 
AHP method [158-161], which can be obtained by traditional means. The network layer is a network structure that affects each other internally, and the indicators in this layer are dominated by the control layer.

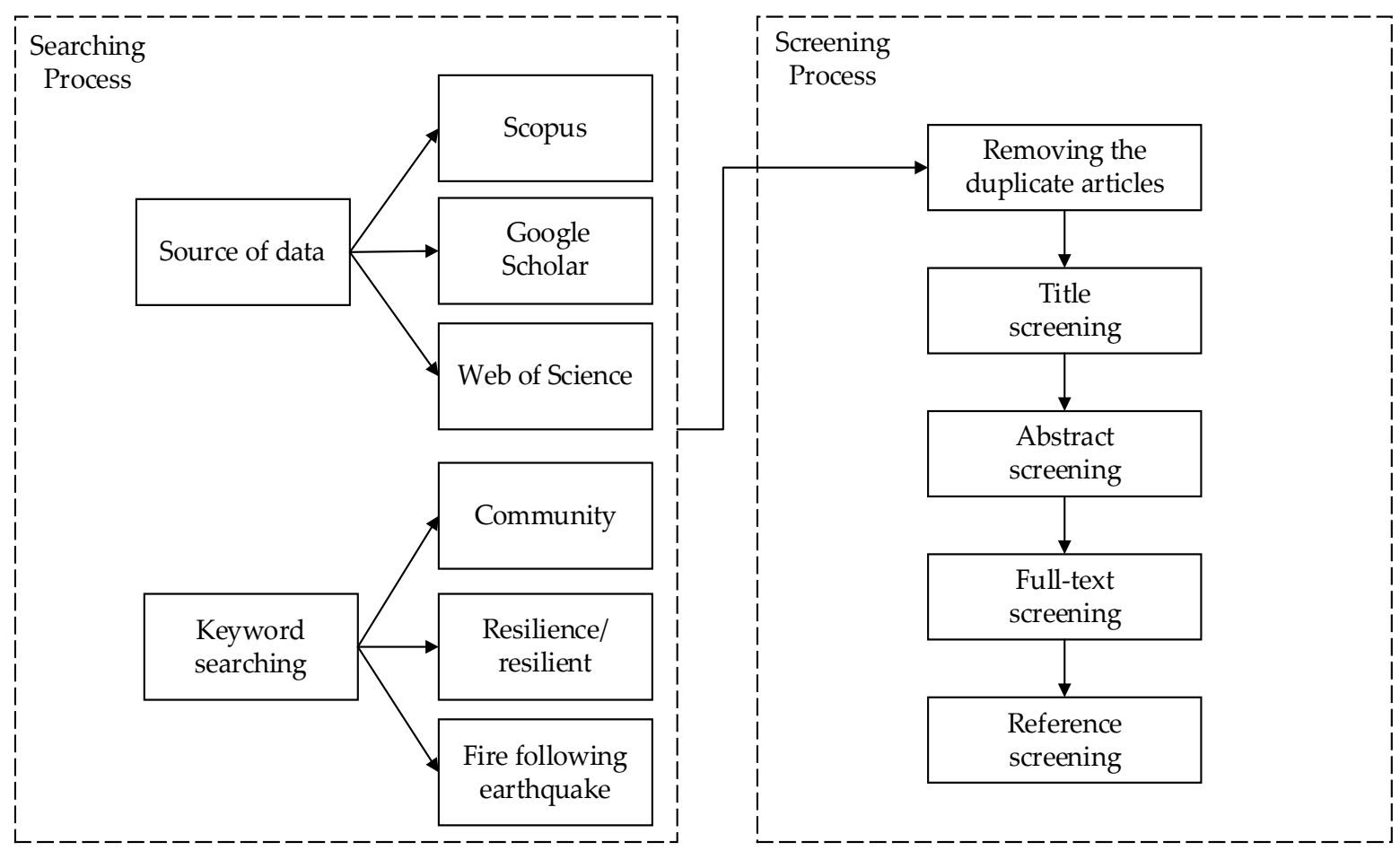

Figure 1. Flowchart of the systematic literature review.

\subsection{MCDA Method Selection}

Due to the complexity of different dimensions for the assessment indicators, the decision-makers require effective and systematic methods to fulfill the decision-making process. On this basis, the MCDA methods are widely applied when tackling issues with a multitude of conflicting objectives. In response to these needs, many solutions dedicated to selected areas, as well as general-purpose methods, have been developed. The evaluation methods are crucial to implementing the conducted evaluation index system. MCDA is designed to provide schemes among limited alternatives for decision-makers from the aspects of actions, goals, solutions, or candidates [162-164]. As measuring the community resilience adaptability to a FFE scenario is a multiple criterion assessment process, the options for the methodology were from the set of MCDA methods considering attributes, characteristics, or goals. The most widely used MCDA includes techniques for order of preference by similarity to ideal solution (TOPSIS) [165], complex proportional assessment (COPRAS), multicriteria optimization and compromise solutions (VIKOR) [166], and preference ranking organization method with rich evaluation content (PROMETHEE), superiority and inferiority ranking (SIR) [167], analytic hierarchy process (AHP), goal programming (GP), ELECTRE I, II, III, IV, IS, TRI [168,169], etc.

The most significant objective of MCDA methods is to help a decision-maker in selecting the most preferable element from a set of possible alternatives. Subjectivity which characterizes the importance of each criterion, impacts the practical result of the assessment. Most decision-makers have a preference where they regard a group of indicators as typically more important than others [170-172]. Moreover, the type of data that could bring uncertainty also has a substantial influence on the subjectivity of assessment. On this basis, a series of influences factors determine the advantages or shortcomings in applying these MCDA methods. For instance, the topic, the complexity of the proposed problems, the users' preferences and adapted evaluation criteria, the form and validation of data, 
researchers' requirements for sensitivity, and the availability of implementations are the most critical consideration for choosing the MCDA methods [173-175].

Prior studies have pointed out that different MCDA methods can present conflicting results in comparison research. For instance, Li et al. [176] developed a generalized framework to help decision-makers to select a suitable MCDA method and software. Kolios et al. [177] carried out a comparative study among a set of widely-applied MCDA methods to determine the best choice from the alternatives. Their findings revealed that more complicated methods, such as TOPSIS and PROMETHEE, have better performance when choosing the best decision-making alternative. Sałabun et al. [178] identified and selected a set of MCDA methods and benchmarked them by using different weighing methods and implementing various approaches in dealing with the problem of initial data normalization. Watróbski et al. [179] developed a framework for determining suitable MCDA methods according to the characteristics of the studied decision problem. A practical tool has been put forward to help decision-makers to select the rational MCDA methods under a given decision-making situation. The MCDA method selection tool is based on the web platform (www.mcda.it (accessed on 14 August 2021)) and requires the users to select the abilities of the MCDA method according to the particular decision problem.

Hence, in the present study, we used the MCDA method selection tool to determine the suitable MCDA method tailored to the decision problem. The tool provides 9 options for selecting the required abilities from a set of 56 MCDA methods where some general descriptors for the properties of the decision-making problem are provided. For instance, the descriptors for the alternative type of weights are qualitative, quantitative, and relative. Some descriptors provide the alternatives for the type of variants' ranking, including partial ranking and complete ranking. Other descriptors provide the alternatives for the topic of the decision-making problem, including choice, classification, ranking and choice, classification and choice, etc. The matching subset will be presented when each option has been determined. During this selecting process, the quantified weights of criteria, the quantified scale, the preference uncertainty, the topic of ranking and choice, and the complete rank are served as the main significant abilities which the MCDA method needs in the presented study. As a result, the PROMETHEE II method was recommended for this study using the MCDA method selection tool.

\subsection{Obtaining the Ranking of Community Resilience Implementing PROMETHEE II Method}

The PROMETHEE was developed by Brans et al. (1986) [180]. The PROMETHEE uses a set of evaluation criteria (i.e., priority functions) to describe the priority of a limited number of alternatives (individuals) in attributes and ranks the pros and cons of each scheme according to the size of the gap between the attribute values of each scheme. Compared with other MCDA methods, the PROMETHEE method has become one of the most commonly used decision-making methods in solving multi-attribute decisionmaking problems due to its simple and clear execution process and easy understanding by decision-makers. PROMETHEE offers unique advantages of compensating for other MCDA methods due to its simple and clear execution process and ease of being understood by decision-makers in solving multi-attribute decision-making problems [181-185]. The ranking methods of the PROMETHEE series include PROMETHEE I-VI, PROMETHEE Group Decision Support System (GDSS), PROMETHEE GAIA, PROMETHEE TRI, and PROMETHEE CLUSTER. Based on specific mathematical attributes and applications, each of the above-mentioned PROMETHEE methods can be considered as a dedicated evaluation tool for a certain type of decision-making problem. In this study, the PROMETHEE II method [186] was employed to obtain a complete ranking of alternatives. In PROMETHEE II methods, through dealing with the input and output preference flows, the values of net preference flow for individual variants were calculated. Thereafter, a complete ranking of variants could be obtained.

There were 4 steps in conducting the comprehensive assessment on community resilience adapted to FFE: 
1. Establishing the set of indicators, namely a set of various factors that affect the object of assessment. In this study, the set of indicators are interpreted as $\mathrm{E}=\left\{E_{1}, E_{2}, E_{3}, \ldots, E_{\mathrm{n}}\right\}$;

2. Determining the evaluation criteria. The evaluation criteria are a set of collections that describe the expert or community leader's evaluation of various community resilience adapted to FFE. In this study, the set of indicators are interpreted as $\mathrm{C}=\left\{C_{1}, C_{2}, C_{3}, \ldots, C_{\mathrm{n}}\right\}$;

3. Selecting the studied hazard scenario. Due to the different influences of the negative impacts caused by different hazard scenarios in a community, the types and levels of hazards should be limited when evaluating and comparing the relative resilience to hazards of a group of communities. Based on the multi-scenario model comparison function provided by Visual PROMETHEE software, select a single hazard (fire following earthquake) and evaluate the resilience of communities;

4. Result analysis. Based on the PROMETHEE II module of Visual PROMETHEE software, each indicator is used to decide the ranking of the community resilience adapted to FFE, and then the comprehensive priority level value and ranking can be obtained to determine the absolute value.

\section{Empirical Analysis}

\subsection{Background of the Selected Samples}

The selected four communities are located in the southwest region of Yuxi City of Yunnan province in China. As earthquake-prone areas, the four communities experienced an earthquake with Magnitude 5.0 on 13 August 2018. According to the post-disaster statistics of the Yunnan Provincial Earthquake Prevention and Mitigation Bureau, postearthquake fires were the disaster that had the greatest impact on these communities. The basic information of them is demonstrated as follows.

Gaolongtan community (referred to hereafter as G Community) was established in 2003, starting from Damiao mountain in the east to Dongfeng Road in the west, GCLP village in the south, and Xingyun road in the north. It encompasses a total of 2960 households, with a land area of 1.48 square kilometers and a total population of 9730 residents.

Jinxiu community (referred to hereafter as J Community) was established in April 2011, and it is a community under the jurisdiction of Gucheng Street in Yuxi City of Yunnan Province. The community is located on Chongwen Road, west to the center of Naxi River, from the Bell Tower of Minzu Square in the south to the center of Pingdian River in the north, with an area of 5.8 square kilometers. The total number of households in the community is 2354 , and the total population of J Community is 14,000 , where the floating population is more than 10,000 .

Ruixin community (referred to hereafter as R Community) was established in 2014, and it encompasses a total of 3400 households, with a land area of 1.96 square kilometers and a total population of 6330 residents.

Hutian Community (referred to hereafter as H Community) is located in the south of Fenghuang Road, Hongta District of Yuxi City in Yunnan Province. It was established in May 2003, starting from Fuxian Road in the east and neighboring Xingyun in the south. The total area of the community is 0.809 square kilometers, and there are 34 community units. The total number of households in H Community is 4940, and the population is 15,000 .

\subsection{Data and Standardized Interview Adapting Scoring Scale}

We designed the standardized interview adapting scoring scale. Sixty-three interviewees who experienced the earthquake in G, J, R, H Communities were invited from the stakeholders of these Community. These interviewees include staff in street offices, committee leaders of the residents in the community, property service center supervisors, and some representatives for residents. The profile of the responders is listed in Table 2. 
Table 2. Profiles of the responders.

\begin{tabular}{ccccc}
\hline Responders NO. & Roles in the Community & Years & Participants & Percentages \\
\hline 1 & Local citizens & 19 years & 20 & $31.7 \%$ \\
2 & Government branch & 8 years & 7 & $11.1 \%$ \\
3 & Clerk in the community office & 13 years & 10 & $15.9 \%$ \\
4 & Fire department and earthquake administration & 8 years & 4 & $6.3 \%$ \\
5 & Security personnel in the community & 13 years & 4 & $6.3 \%$ \\
6 & Firefighters & 10 years & 5 & $7.9 \%$ \\
7 & Emergency management personnel & 11 years & 3 & $4.8 \%$ \\
8 & Volunteers in the community & 5 years & 10 & $15.9 \%$ \\
\hline
\end{tabular}

\subsection{Determining the Weights of the Indicators Using ANP}

In the process of ANP, the interrelationship between each indicator $\left(C_{i}\right)$ formed an influential network where the nodes are dependent and interact. Hence, in order to determine the weight of each indicator, we needed to make a pairwise comparison between each node of the network. The index scale judgment rules are presented in Table 3.

Table 3. The index scale judgment rules.

\begin{tabular}{ccc}
\hline Scores (S) & Pairwise Comparison & Index for the Importance \\
\hline I & $C_{i} \rightarrow C_{j}$ & $\mathrm{a}$ \\
III & $C_{i} \rightarrow C_{j}$ & $\mathrm{~b}$ \\
V & $C_{i} \rightarrow C_{j}$ & $\mathrm{c}$ \\
VII & $C_{i} \rightarrow C_{j}$ & $\mathrm{~d}$ \\
IX & $C_{i} \rightarrow C_{j}$ & e \\
II, IV, VI, VIII & Median & Between the above indexes \\
1/S & $C_{j} \rightarrow C_{i}$ & Negative values \\
\hline
\end{tabular}

Using the judgment rules, we designed a questionnaire to conduct interviews and a data collection process with 10 experts in the research field and 11 representatives from the four selected communities. They were required to make a comparison between each indicator using the rules proposed in Table 3 and to finish the questionnaire. Thereafter, we collected the results of the questionnaire and input the results into ANP analysis platform. The final relationship network is presented in the form of a matrix in Table 4.

Table 4. Pairwise comparison for the interrelationship between each indicator.

\begin{tabular}{|c|c|c|c|c|c|c|c|c|c|c|c|c|c|c|c|c|c|c|c|c|}
\hline $\mathrm{C}(i)$ & & 2 & 3 & 4 & 5 & 6 & 7 & 8 & 9 & 10 & 11 & 12 & 13 & 14 & 15 & 16 & 17 & 18 & 19 & 20 \\
\hline 1 & & 1 & & 1 & & & & & & & & & 1 & & & & & 1 & & \\
\hline $\begin{array}{l}2 \\
3\end{array}$ & & & & & & 1 & & 1 & & & 1 & 1 & & 1 & & 1 & & & & \\
\hline 4 & 1 & 1 & & & & & & & & & & & & & & & & & 1 & \\
\hline 5 & 1 & & & 1 & & & & & & & & & & & & & & & & \\
\hline 6 & & 1 & & & & & & & & & & 1 & & & & & & & & \\
\hline 7 & & & & & & & & 1 & & & & & & & & & & & & \\
\hline 8 & & & & & 1 & & & & & & & & & & & & & & 1 & \\
\hline 9 & & & 1 & & & & & & & 1 & & & & & & & & & & \\
\hline 10 & & & & & & & & & & & & & & & & & & & & \\
\hline 11 & & & & & & & & & & & & & & & 1 & 1 & & 1 & & \\
\hline 12 & & & & & & & 1 & & & & & & & 1 & 1 & & & & & \\
\hline 13 & & & & & & & & & & & & & & & & & & 1 & & \\
\hline 14 & & & & & & & & & & & 1 & & & & 1 & & & 1 & & \\
\hline 15 & & 1 & & & & 1 & & & & & & & & & & & & & & \\
\hline 16 & & 1 & & & & & & & & & & & & & 1 & & & & & \\
\hline 17 & 1 & & & & & & & & 1 & 1 & & & & & & & & & & \\
\hline 18 & & & & & & & & & & & & & & 1 & & & & & & \\
\hline 19 & & & & & 1 & & & & & & & 1 & & & & & & & 1 & \\
\hline 20 & & 1 & & & & & & & & & & & & & & & & & & \\
\hline
\end{tabular}


By applying the ANP analysis platform, the final weights of the indicators of community resilience adapted to FFE were generated and presented in Table 5.

Table 5. Indicators and weights of community resilience adapted to FFE.

\begin{tabular}{cccc}
\hline Number & Code & Indicators & Weights \\
\hline 1 & $C_{1}$ & Safety and health of residents & 0.1250 \\
2 & $C_{2}$ & Participation rate of stakeholders & 0.0256 \\
3 & $C_{3}$ & Earthquake and fire prevention knowledge & 0.0753 \\
4 & $C_{4}$ & Chaos following an earthquake & 0.0159 \\
5 & $C_{5}$ & Response time of the firefighters & 0.0570 \\
6 & $C_{6}$ & External support & 0.0167 \\
7 & $C_{7}$ & Emergency management capabilities & 0.0483 \\
8 & $C_{8}$ & Resource reserve & 0.0291 \\
9 & $C_{9}$ & Anti-seismic and fire-proof design of buildings & 0.1074 \\
10 & $C_{10}$ & Finances of the community & 0.0256 \\
11 & $C_{11}$ & Communication systems & 0.0175 \\
12 & $C_{12}$ & Transportation systems & 0.0387 \\
13 & $C_{13}$ & Security systems & 0.0139 \\
14 & $C_{14}$ & Firefighting systems & 0.0198 \\
15 & $C_{15}$ & Gas supply systems & 0.0345 \\
16 & $C_{16}$ & Water supply systems & 0.0284 \\
17 & $C_{17}$ & Electricity supply systems & 0.1501 \\
18 & $C_{18}$ & Active fire control systems & 0.0492 \\
19 & $C_{19}$ & Sewage systems & 0.0962 \\
20 & $C_{20}$ & Waste treatment systems & 0.0256
\end{tabular}

\subsection{Comprehensive Assessment on the Community Resilience Adapted to FFE}

We designed and applied Liszt's five-level scale for each item of the questionnaire. Respondents need to assess the resilience of G, J, R, H communities on a scale of " $1-5$ " values toward fire following the earthquake in August 2018. The rating results are listed in Table 6.

Table 6. The resilience of G, J, R, H communities adapting Liszt's five-level scale.

\begin{tabular}{|c|c|c|c|c|c|}
\hline Number & Indicators & G & $\mathbf{J}$ & $\mathbf{R}$ & $\mathbf{H}$ \\
\hline 1 & Safety and health of residents & 4 & 4 & 5 & 2 \\
\hline 2 & Participation rate of stakeholders & 3 & 4 & 5 & 3 \\
\hline 3 & Earthquake and fire prevention knowledge & 5 & 3 & 5 & 3 \\
\hline 4 & Chaos following an earthquake & 3 & 2 & 4 & 4 \\
\hline 5 & Response time of the firefighters & 3 & 5 & 3 & 4 \\
\hline 6 & External support & 4 & 3 & 2 & 4 \\
\hline 7 & Emergency management capabilities & 3 & 3 & 5 & 4 \\
\hline 8 & Resource reserve & 3 & 4 & 4 & 3 \\
\hline 9 & Anti-seismic and fire-proof design of buildings & 4 & 2 & 3 & 1 \\
\hline 10 & Finances of the community & 4 & 3 & 3 & 4 \\
\hline 11 & Communication systems & 5 & 5 & 3 & 3 \\
\hline 12 & Transportation systems & 5 & 2 & 2 & 2 \\
\hline 13 & Security systems & 4 & 1 & 2 & 3 \\
\hline 14 & Firefighting systems & 4 & 4 & 4 & 4 \\
\hline 15 & Gas supply systems & 4 & 5 & 5 & 3 \\
\hline 16 & Water supply systems & 5 & 3 & 2 & 1 \\
\hline 17 & Electricity supply systems & 5 & 4 & 4 & 2 \\
\hline 18 & Active fire control systems & 4 & 2 & 1 & 2 \\
\hline 19 & Sewage systems & 4 & 2 & 1 & 5 \\
\hline 20 & Waste treatment systems & 4 & 2 & 3 & 1 \\
\hline
\end{tabular}

After obtaining the outputs in Table 3, we calculated the community post-hazardadapting resilience toward fire following earthquake using PROMETHEE software. The net flow ranking chart of the four communities for post-hazard-adapting resilience is displayed in Figure 2. The scoring maps of G, J, R, and H communities for resilience adapted to FFE are presented in Figures 3-6, respectively. 


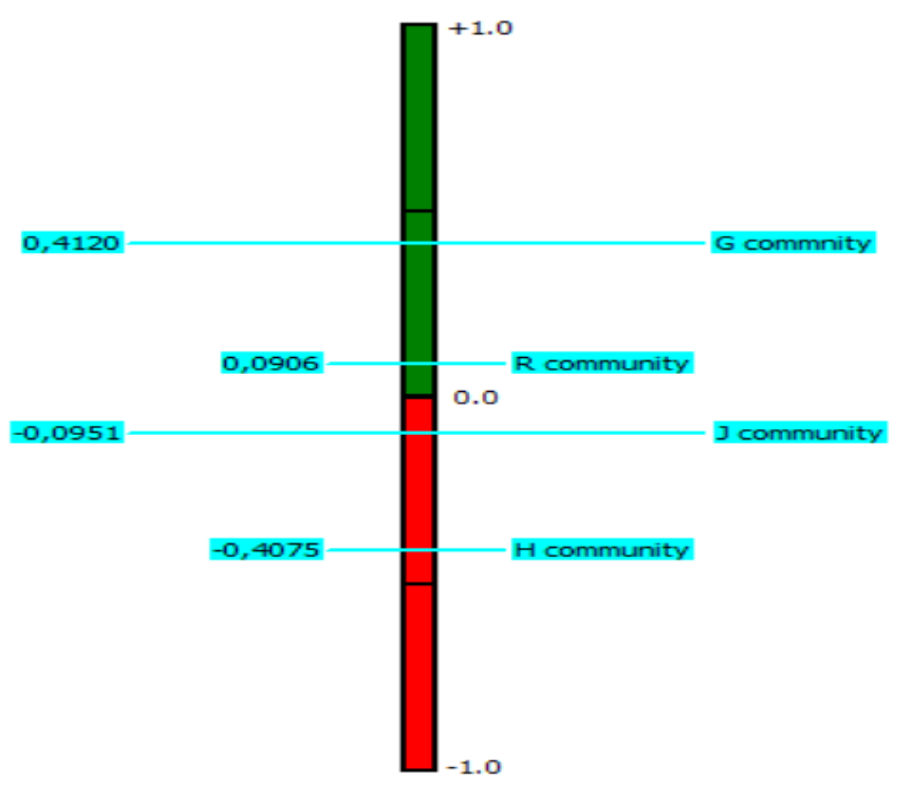

Figure 2. Net flow ranking chart of the four communities for resilience adapted to FFE.

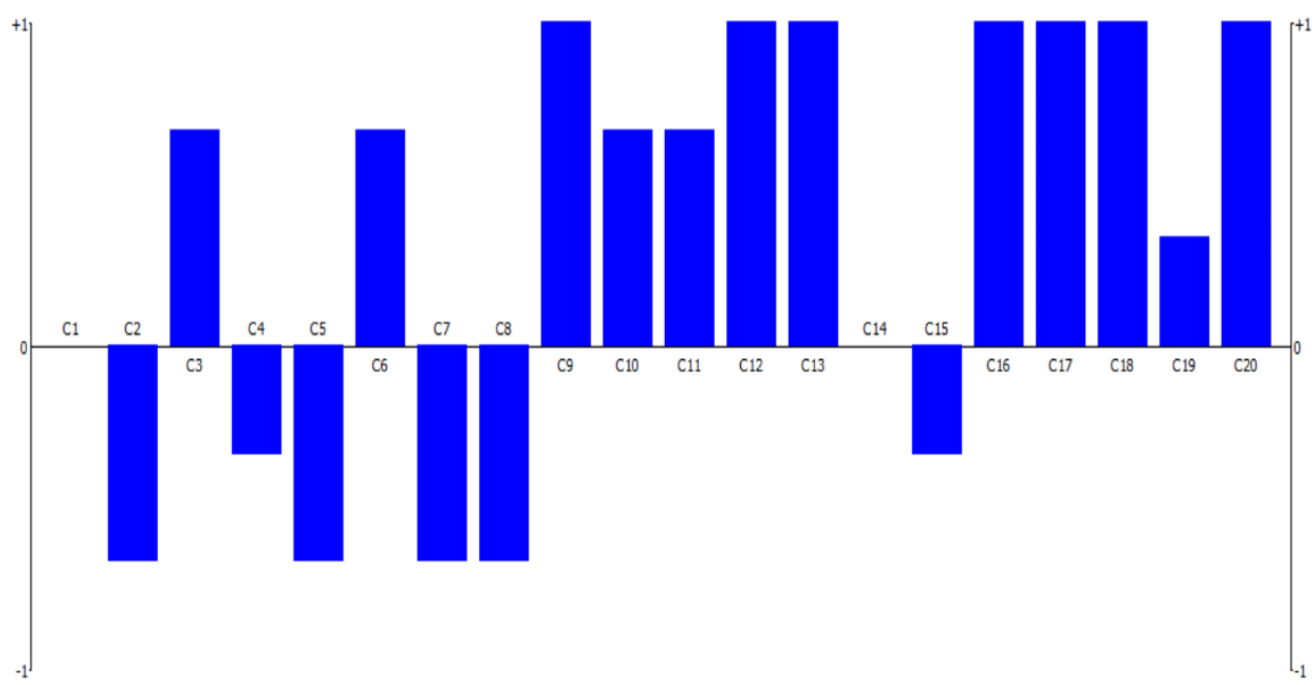

Figure 3. Scoring map of G community for resilience adapted to FFE.

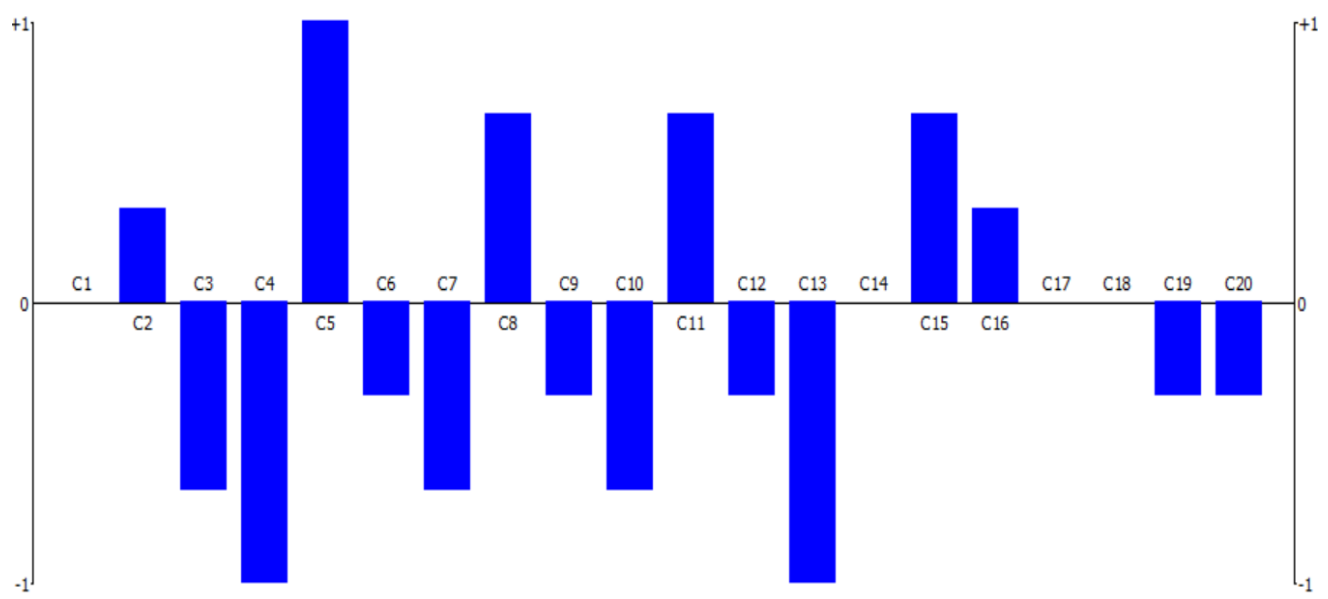

Figure 4. Scoring map of J community for resilience adapted to FFE. 


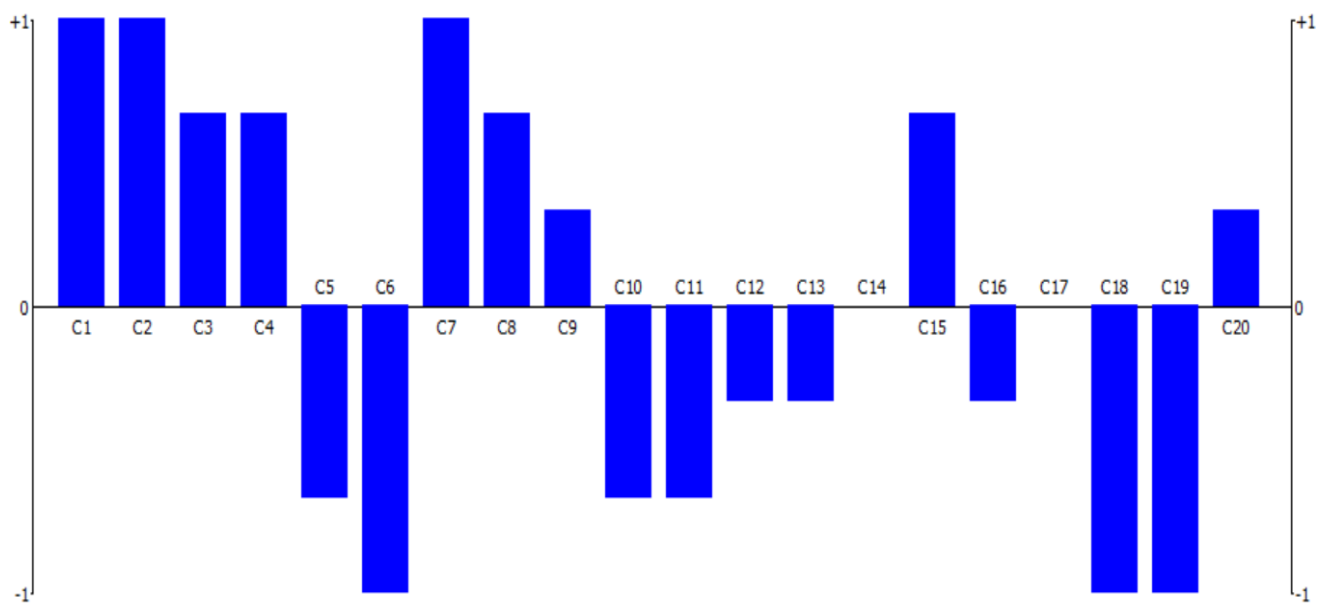

Figure 5. Scoring map of R community for resilience adapted to FFE.

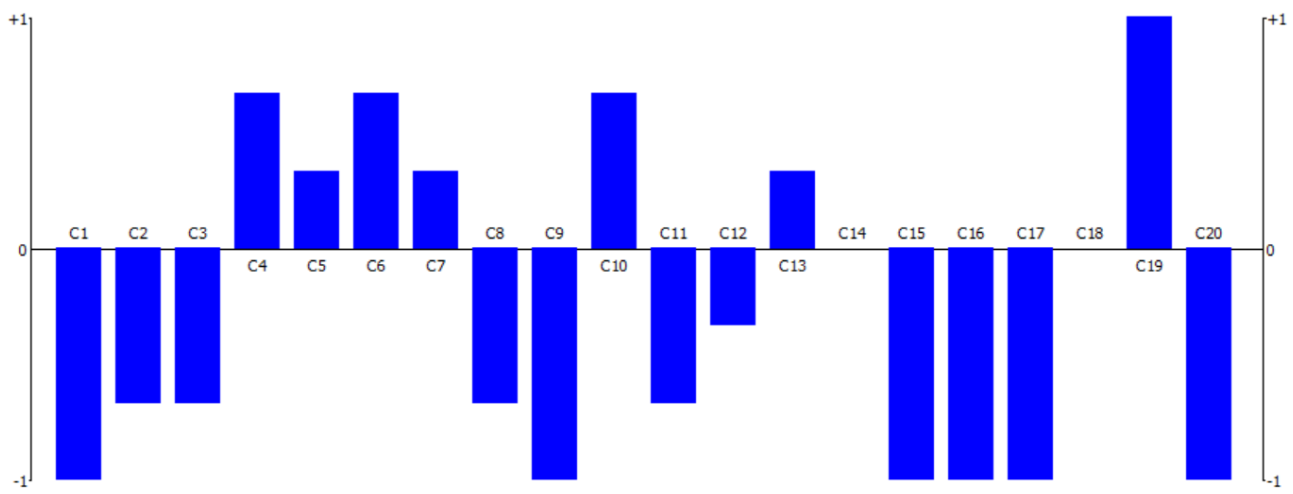

Figure 6. Scoring map of $\mathrm{H}$ community for resilience adapted to FFE.

\section{Results and Discussion}

\subsection{Results Analysis}

(1) Graphical analysis for interactive aid on assessment results

The results of assessment for community post-hazard-adapting resilience toward fire following earthquake could be analyzed by the Graphical Analysis for Interactive Aid (GAIA), an auxiliary analysis tool provided by PROMETHEE. GAIA provides threedimensional spatial analysis diagrams based on different dimensional perspectives, including U-V, U-W, and W-V coordinate systems. Taking the U-V coordinate systems as an example, the GAIA analysis diagram is presented in Figure 6.

In the U-V coordinate systems of GAIA, 79\% of the information in the three-dimensional spatial analysis diagrams could be demonstrated in the map. The red line represents the decision axis. The longer the length of the decision axis, the more information expressed on the plane, and the more accurate the decision. When a certain decision criterion is the same or similar to the direction of the decision axis, it means that the criterion meets the current evaluation standard. If the decision-maker believes that the current result is not what they expected, they should consider adjusting the weight of other evaluation criteria. Therefore, in Figure 7 , when the indicators $C_{16}, C_{17}$, and $C_{14}$ were determined to be the assessment criteria, $\mathrm{G}$ and $\mathrm{R}$ communities were considered to be the mean objectives for the decision making. Similar discussions could be made on U-V coordinate systems of GAIA (Figure 7), W-U coordinate systems of GAIA (Figure 8) and V-W coordinate systems of GAIA (Figure 9), accordingly. 


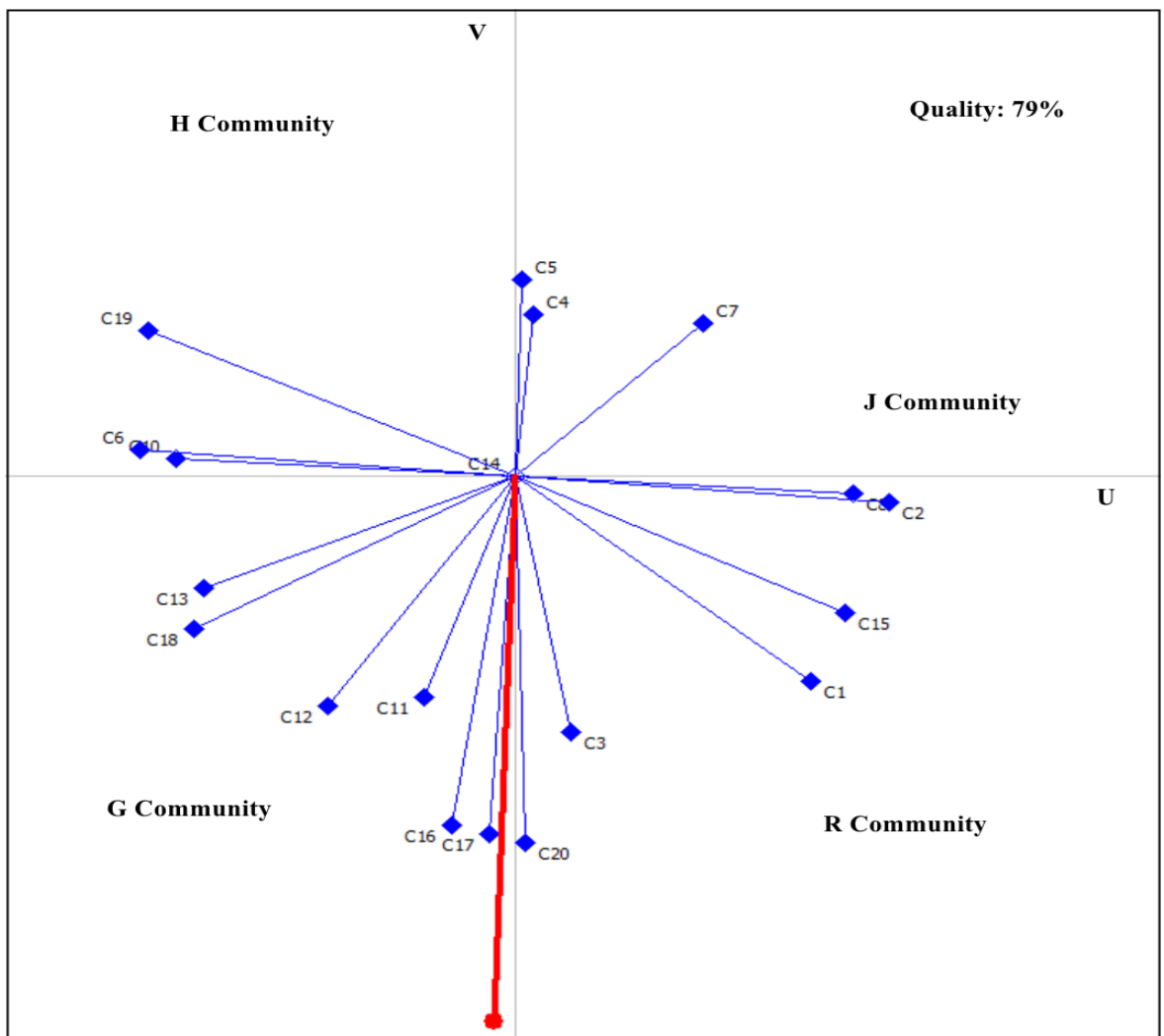

Figure 7. Graphical analysis for interactive aid with U-V coordinate systems.

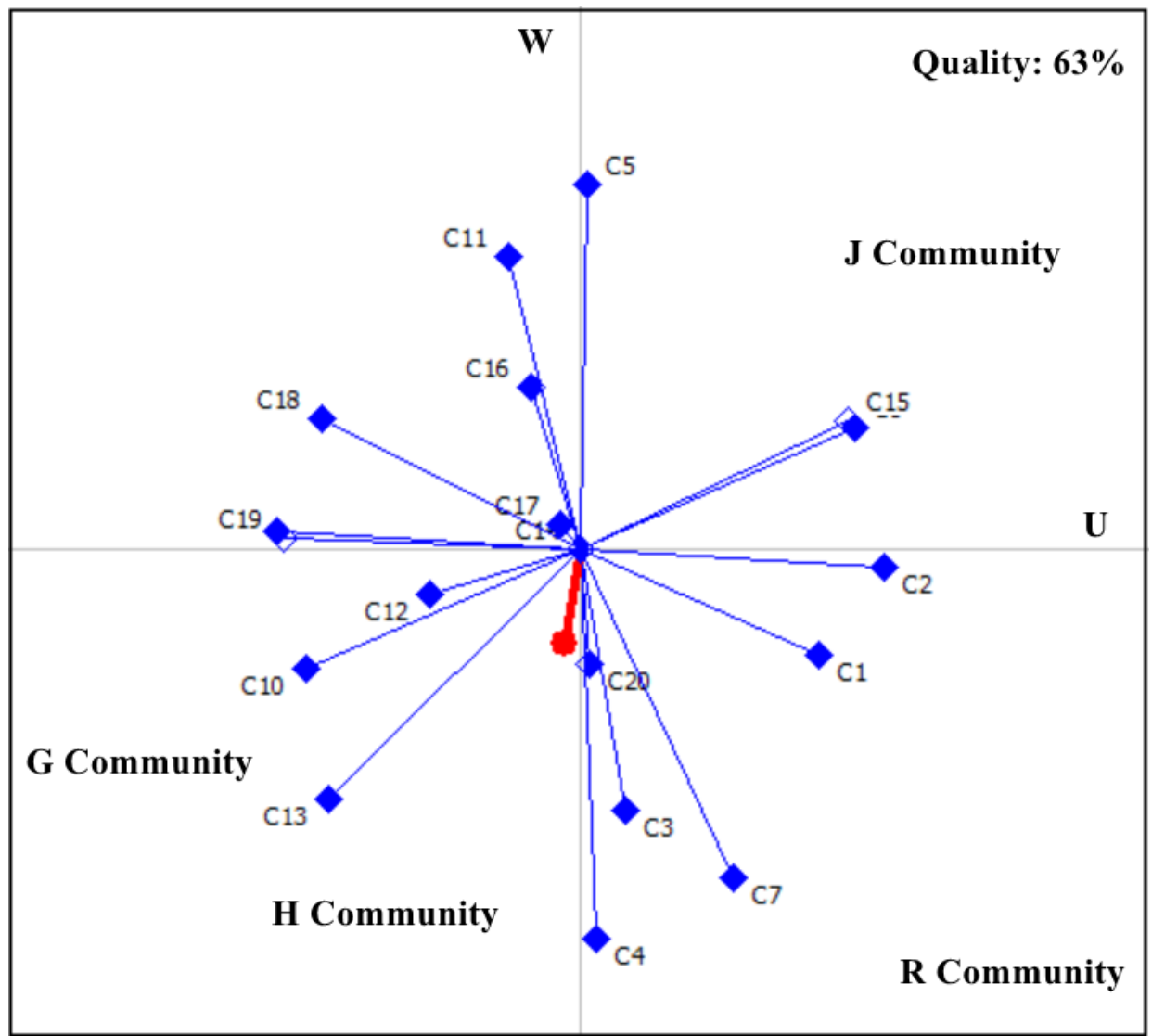

Figure 8. Graphical analysis for interactive aid with W-U coordinate systems. 


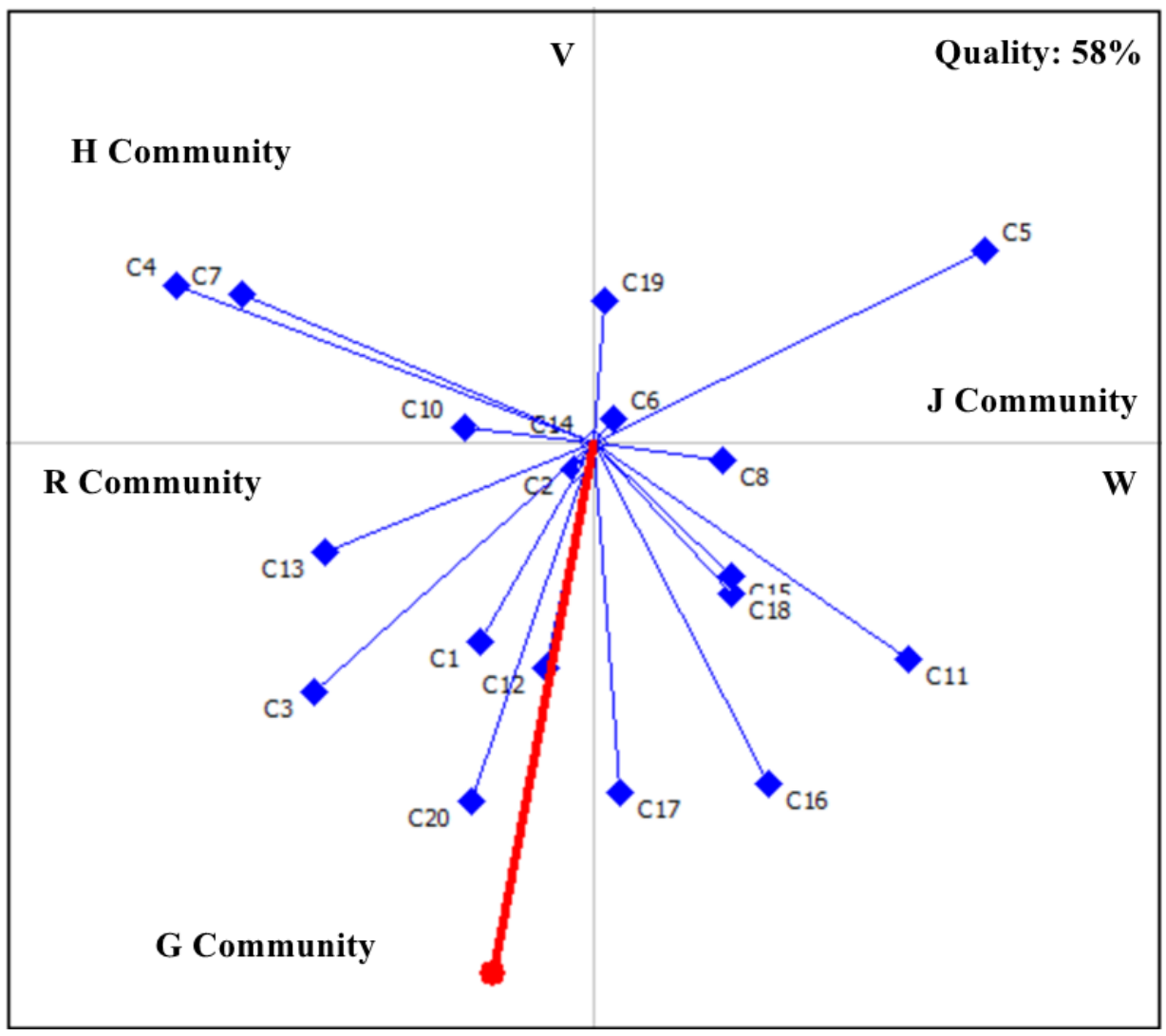

Figure 9. Graphical analysis for interactive aid with V-W coordinate systems.

(2) Net traffic ranking analysis of the four communities for assessment results.

Through implementing net traffic ranking analysis (Figure 2), the net traffic of the four communities after experiencing the earthquake with Magnitude 5.0 on 13 August 2018, could be obtained. The post-hazard-adapting resilience of the four communities under a fire following earthquake scenario was also ranked. The reference interval of the community resilience adapted to FFE was from -1 to 1 , and the rank of the post-hazard-adapting resilience of four communities could be determined.

The findings of net traffic ranking analysis (Figure 2) revealed that the post-hazardadapting resilience of $\mathrm{G}$ Community arrived at 0.412 , which is the highest among the four communities. The performance of the G Community was excellent. Meanwhile, the post-hazard-adapting resilience of $\mathrm{R}$ Community arrived at 0.0906 , which was the second highest among the four communities. However, the post-hazard-adapting resilience of J Community reached-0.0951, which means that its outflow was greater than inflow. Moreover, the post-hazard-adapting resilience of H Community was -0.4075 , namely, the performance of $\mathrm{H}$ Community was the worst of the others.

(3) Comparison analysis on post-hazard-adapting resilience indicators

First, Figure 2 reveals the changes in the net flow of each community post-hazardadapting resilience indicator after experiencing fire following earthquake in the $\mathrm{G}$ community. It could be drawn that $C_{1}$ (safety and health of residents) and $C_{14}$ (firefighting systems) were not affected by the disaster. Both indicators can maintain their functionalities after fire following earthquake. The stability of the firefighting systems is vital for the suppression and mitigation of fire following earthquake.

$C_{3}, C_{6}, C_{9}-C_{13}, C_{16}-C_{20}$ arrived at a positive net flow of community post-hazardadapting resilience after fire following earthquake. That means these indicators have achieved better performance by systematic self-organizing and changing in a resilient community. Furthermore, $C_{9}$ (anti-seismic and fire-proof design of buildings), $C_{12}$ (trans- 
portation systems), $\mathrm{C}_{13}$ (security systems), $\mathrm{C}_{16}$ (water supply systems), $\mathrm{C}_{17}$ (electricity supply systems), $\mathrm{C}_{18}$ (active fire control systems), and $\mathrm{C}_{20}$ (waste treatment systems), which belong to the group of urban infrastructures, had the highest positive net flow among all the indicators. It could be drawn that $\mathrm{G}$ community has a strong degree of infrastructure resilience.

However, $\mathrm{C}_{2}, \mathrm{C}_{4}, \mathrm{C}_{5}, \mathrm{C}_{7}, \mathrm{C}_{8}$, and $\mathrm{C}_{15}$ arrived at a negative net flow of community posthazard-adapting resilience after fire following earthquake. Especially, $C_{2}$ (participation rate of stakeholders), $C_{5}$ (response time of the community), $C_{7}$ (emergency management capabilities), and $\mathrm{C}_{8}$ (resource reserve) had the highest negative net flow among all the indicators. More extensive efforts should be exerted to improve these indicators to achieve a resilient community.

Second, Figure 3 reveals the changes in the net flow of each community post-hazardadapting resilience indicator after experiencing fire following earthquake in the J community. It could be drawn that $C_{1}$ (safety and health of residents), $C_{14}$ (firefighting systems), $\mathrm{C}_{17}$ (electricity supply systems), and $\mathrm{C}_{18}$ (active fire control systems) were not affected by fire following earthquake. All four indicators can maintain their functionalities after fire following earthquake. Moreover, the functionalities of $\mathrm{C}_{14}$ (firefighting systems) and $\mathrm{C}_{18}$ (active fire control systems) are vital for the suppression and mitigation of fire following earthquake.

$\mathrm{C}_{2}, \mathrm{C}_{5}, \mathrm{C}_{8}, \mathrm{C}_{11}, \mathrm{C}_{15}$, and $\mathrm{C}_{16}$ arrived at a positive net flow of community post-hazardadapting resilience after fire following earthquake. Furthermore, $\mathrm{C}_{5}$ (response time of the community) had the highest positive net flow among all the indicators. However, $\mathrm{C}_{3}, \mathrm{C}_{4}$, $\mathrm{C}_{6}, \mathrm{C}_{7}, \mathrm{C}_{9}, \mathrm{C}_{10}, \mathrm{C}_{12}, \mathrm{C}_{13}, \mathrm{C}_{19}$, and $\mathrm{C}_{20}$ arrived at the negative net flow of community posthazard-adapting resilience after fire following earthquake. Especially, $\mathrm{C}_{4}$ (chaos following an earthquake) and $C_{13}$ (security systems) had the highest negative net flow among all the indicators. More extensive efforts should be exerted to improve these indicators to achieve a resilient community.

Third, Figure 4 reveals the changes in the net flow of each community post-hazardadapting resilience indicator after experiencing fire following earthquake in the $\mathrm{R}$ community. It could be drawn that $\mathrm{C}_{14}$ (firefighting systems) and $\mathrm{C}_{17}$ (electricity supply systems) were not affected by fire following earthquake. Both indicators could maintain their functionalities after experiencing fire following earthquake. The stability of the firefighting systems and electricity supply systems are vital for the suppression and mitigation of fire following earthquake.

$\mathrm{C}_{1}-\mathrm{C}_{4}, \mathrm{C}_{7}-\mathrm{C}_{9}, \mathrm{C}_{15}$, and $\mathrm{C}_{20}$ arrived at a positive net flow of community post-hazardadapting resilience after fire following earthquake. Furthermore, $C_{1}$ (safety and health of residents), $C_{2}$ (participation rate of stakeholders), and $C_{7}$ (emergency management capabilities) had the highest positive net flow among all the indicators. However, $\mathrm{C}_{5}$, $\mathrm{C}_{6}, \mathrm{C}_{10}-\mathrm{C}_{13}, \mathrm{C}_{16}, \mathrm{C}_{18}$, and $\mathrm{C}_{19}$ arrived at a negative net flow of community post-hazardadapting resilience after fire following earthquake. Especially, $\mathrm{C}_{6}$ (external support), $\mathrm{C}_{18}$ (active fire control systems), and $\mathrm{C}_{19}$ (sewage systems) had the highest negative net flow among all the indicators. More extensive efforts should be exerted to improve these indicators to achieve a resilient community.

Forth, Figure 5 reveals the changes in the net flow of each community post-hazardadapting resilience indicator after experiencing fire following earthquake in the $\mathrm{H}$ community. It could be drawn that $C_{14}$ (firefighting systems) and $C_{18}$ (active fire control systems) were not affected by fire following earthquake. Both indicators could maintain their functionalities after experiencing fire following earthquake. The stability of the firefighting systems and electricity supply systems are vital for the suppression and mitigation of fire following earthquake.

$\mathrm{C}_{4}-\mathrm{C}_{7}, \mathrm{C}_{10}, \mathrm{C}_{13}$, and $\mathrm{C}_{19}$ arrived at a positive net flow of community post-hazardadapting resilience after fire following earthquake. Furthermore, $\mathrm{C}_{19}$ (sewage systems) had the highest positive net flow among all the indicators. However, $C_{1}-C_{3}, C_{8}, C_{9}, C_{11}$, $\mathrm{C}_{12}, \mathrm{C}_{15}-\mathrm{C}_{17}$, and $\mathrm{C}_{20}$ arrived at a negative net flow of community post-hazard-adapting 
resilience after fire following earthquake. Especially, $C_{1}$ (safety and health of residents), $\mathrm{C}_{9}$ (anti-seismic and fire-proof design of buildings), $\mathrm{C}_{15}$ (gas supply systems), $\mathrm{C}_{16}$ (water supply systems), $C_{17}$ (electricity supply systems), and $C_{20}$ (waste treatment systems) had the highest negative net flow among all the indicators. More extensive efforts should be exerted to improve these indicators to achieve a resilient community.

\subsection{Disscussion}

To make a comprehensive comparison of the performance of the four samples, the G community had an excellent performance on the categories of "design and financial support" and "the function of urban infrastructure". That means a lot of resources have been invested in community infrastructure systems and resilience support systems by the community manager. However, due to the poor performance of the $\mathrm{G}$ community in the category of "management and resource", greater benefits could be yielded if intensive care was exerted to these weak indicators. When considering the limitation of resources in a community, the community managers should allocate resources from the categories of "design and financial support" and "the function of urban infrastructure" to the "management and resource" to achieve resource optimization and improve community resilience.

The whole community resilience performance of the J community was poor. There were 6 positive scores and 10 negative for the J community. "Response time of the firefighters" was the indicator that had the highest score in the six positive scores. However, the indicators of "earthquake and fire prevention knowledge", "chaos following an earthquake", "emergency management capabilities", "finances of the community", and "security systems" had evidently poor performance, with most of them belonging to the category of "management and resource". Limited resources were allocated to the category of "management and resource" and weak strategies were implemented by policy-makers in J community.

The R community had an excellent performance in the category of "management and resource". However, it presented low scores in the categories of "design and financial support" and "the function of urban infrastructure". A lot of investment in the R community was used to build resilient organizations and connections, but the construction of physical systems, such as infrastructure construction, was very weak. Planning and strategies for the achieving of a resilient community should be adjusted accordingly.

Though the $\mathrm{H}$ community won the highest score for the indicators of "sewage systems", it had weak performance in all three categories. The resilience performance of the $\mathrm{H}$ community determined that it would be a very unstable system when a disaster occurs. Extensive resilience enhancement strategies should be applied to improve the disaster prevention and mitigation capabilities of the community.

The final comparison results on a comprehensive assessment of relative scores are demonstrated in Table 7. It can be drawn from the comprehensive assessment of relative scores of the four communities toward three different criteria tiers that the G Community won the highest score and had the strongest performance in the groups of design and financial support and the function of urban infrastructure, respectively. Meanwhile, the $\mathrm{R}$ Community won the highest score in the group of management and resource. However, $\mathrm{H}$ Community had the lowest score according to the result of the comprehensive assessment.

Table 7. Final comparison results on the comprehensive assessment of relative scores.

\begin{tabular}{|c|c|c|c|c|c|}
\hline Number & Criteria Tier & G Community & J Community & R Community & H Community \\
\hline 1 & Management and resource & 88.72 & 53.62 & 100 & 76.28 \\
\hline 2 & Design and financial support & 100 & 90.31 & 78.96 & 52.1 \\
\hline 3 & $\begin{array}{l}\text { The function of urban } \\
\text { infrastructure }\end{array}$ & 100 & 96.02 & 71.23 & 63.25 \\
\hline
\end{tabular}




\section{Conclusions}

At present, sustainable development goals in multi-domain have drawn great attention in response to handling the changing and deteriorating environment for the survival and development of human beings. A resilient city and community are required when facing natural hazards, which could bring huge losses and damage to human society. Historical events have shown that FFE is the most influential one. Hence, this study conducted a comprehensive assessment on community post-hazard-adapting resilience under a fire post-earthquake scenario.

In this study, 20 indicators on community resilience adapted to FFE were identified using SLR. Thereafter, the weights of the indicators were determined using ANP. Four communities in Yuxi City of Yunnan province in China were selected to fulfill the empirical analysis. The PROMETHEE II technique was employed to make a multicriteria assessment. The results of the assessment were demonstrated in the form of a net flow ranking chart. Additionally, graphical analysis for interactive aid on assessment results was implemented. The findings showed that the indicators on community post-hazard-adapting resilience were significantly changed after FFE. The resilience assessment results of the $G$ community indicated that policy and strategy preferences should be imposed to reinforce the indicators in the category of "management and resource" by municipal decision-makers. Because of the poor community resilience performance of the whole J community, extensive efforts should be exerted to the negative indictors in the three categories by municipal decisionmakers. The resilience assessment results of the $\mathrm{R}$ community revealed that the policy and strategy preferences of municipal decision-makers should be adjusted to improve the physical infrastructure construction and economic and social environment. As an unstable system for the $\mathrm{H}$ community, extensive resilience enhancement strategies should be carried out to improve the community resilience of all aspects.

Final comparison results on the comprehensive assessment of relative scores revealed that the G Community won the highest score and had the strongest performance. However, $\mathrm{H}$ Community had the lowest score according to the result of the comprehensive assessment.

A few limitations should be acknowledged. The primary findings were based on the investigation of earthquake-prone areas. Due to low earthquake risk in many locations, the proposed indicators on community resilience under a FFE scenario should be adjusted to adapt to the most influential risks locally $[187,188]$. However, as the assessment techniques implemented in this study is simple and valid, it could be applied to assess more disaster scenarios. It will benefit the policy-makers and make some useful suggestion in the process of achieving the sustainable development goals.

Author Contributions: Conceptualization, Z.H. and H.C.; methodology, Z.H., Q.Q. and T.W.; software, H.Y.; validation, Z.H., H.C. and Q.Q.; formal analysis, H.Y. and T.W.; investigation, Q.Q. and H.C.; resources, Z.H.; data curation, Z.H.; writing-original draft preparation, Z.H.; writing—review and editing, H.C.; visualization, Y.Y. and Q.Q.; supervision, H.C.; project administration, H.C.; funding acquisition, H.C. All authors have read and agreed to the published version of the manuscript.

Funding: This research was funded by Natural Science Foundation of Hunan Province, grant number [2021JJ30861]. The APC was funded by National Natural Science Foundation of China, grant number [71273283].

Conflicts of Interest: The authors declare no conflict of interest.

\section{References}

1. Domingo-Echaburu, S.; Dávalos, L.; Orive, G.; Lertxundi, U. Drug pollution \& Sustainable Development Goals. Sci. Total Environ. 2021, 800, 149412. [CrossRef]

2. Haskins, C. Systems Engineering for Sustainable Development Goals. Sustainability 2021, 13, 10293. [CrossRef]

3. Kim, J.J.; Goodwin, C.W.; Kim, S. Communication Turns Green Construction Planning into Reality. J. Green Build. 2017, 12, 168-186. [CrossRef]

4. Lehmann, S. Resource recovery and materials flow in the city: Zero waste and sustainable consumption as paradigm in urban development. J. Green Build. 2011, 6, 88-105. [CrossRef] 
5. Wu, P.; Feng, Y. Using Lean Practices to Improve Current Carbon Labelling Schemes for Construction Materials-A General Framework. J. Green Build. 2012, 7, 173-191. [CrossRef]

6. Chen, Y.; Liu, T.; Ge, Y.; Xia, S.; Yuan, Y.; Li, W.; Xu, H. Examining social vulnerability to flood of affordable housing communities in Nanjing, China: Building long-term disaster resilience of low-income communities. Sustain. Cities Soc. 2021, $71,102939$. [CrossRef]

7. Butters, C.; Cheshmehzangi, A.; Sassi, P. Cities, Energy and Climate: Seven Reasons to Question the Dense High-Rise City. J. Green Build. 2020, 15, 197-214. [CrossRef]

8. Lehmann, S. Towards a Sustainable City Centre: Integrating Ecologically Sustainable Development (ESD) Principles into Urban Renewal. J. Green Build. 2006, 1, 83-104. [CrossRef]

9. Lee, K.; Park, C. The Sustainable Micro-Scale Movement of Communities: Case Studies of Subdivided Development and Adaptive Reuse of Shared Space in New York City. J. Green Build. 2016, 11, 23-37. [CrossRef]

10. Hendee, B.A. Sustainable Site Development. J. Green Build. 2006, 1, 9-20. [CrossRef]

11. Ahn, Y.H.; Kwon, H.; Pearce, A.R.; Wells, J.G. The Systematic Course Development Process: Building a Course in Sustainable Construction for Students in the USA. J. Green Build. 2009, 4, 169-182. [CrossRef]

12. Lee, J.; Shepley, M. The Green Standard for Energy and Environmental Design (G-Seed) for Multi-Family Housing Rating System in Korea: A Review of Evaluating Practices and Suggestions for Improvement. J. Green Build. 2019, 14, 155-175. [CrossRef]

13. Pujadas-Gispert, E.; Korevaar, C.; Alsailani, M.; Moonen, S. Linking Constructive and Energy Innovations for a Net Zero-Energy Building. J. Green Build. 2020, 15, 153-184. [CrossRef]

14. Fakourian, F.; Asefi, M. Environmentally Responsive Kinetic Façade for Educational Buildings. J. Green Build. 2019, 14, 165-186. [CrossRef]

15. Farzinmoghadam, M.; Mostafavi, N.; Infield, E.H.; Hoque, S. Developing an Automated Method for the Application of Lidar in Iumat Land-Use Model: Analysis of Land-Use Changes Using Building-Form Parameterization, Gis, and Artificial Neural Networks. J. Green Build. 2019, 14, 1-30. [CrossRef]

16. Wuni, I.Y.; Shen, G.Q.; Osei-Kyei, R. Sustainability of Off-Site Construction: A Bibliometric Review and Visualized Analysis of Trending Topics and Themes. J. Green Build. 2020, 15, 131-154. [CrossRef]

17. Lwin, M.; Panuwatwanich, K. Identification and Evaluation of Green Building Assessment Indicators for Myanmar. J. Green Build. 2021, 16, 143-172. [CrossRef]

18. Bahho, M.; Vale, B. A Demonstration Building Project: Promoting Sustainability Values. J. Green Build. 2020, 15, 91-112. [CrossRef]

19. Qin, L.; Wang, M.; Zhu, J.; Wei, Y.; Zhou, X.; He, Z. Towards Circular Economy through Waste to Biomass Energy in Madagascar. Complexity 2021, 2021, 1-10. [CrossRef]

20. Storms, K.; Simundza, D.; Morgan, E.; Miller, S. Developing a resilience tool for higher education institutions: A must-have in campus master planning. J. Green Build. 2019, 14, 187-198. [CrossRef]

21. Pushkar, S.; Verbitsky, O. Silver and Gold Leed Commercial Interiors: Certified Projects. J. Green Build. 2019, 14, 95-113. [CrossRef]

22. Bray, J.; McCurry, N. Unintended Consequences: How the Use of LEED Can Inadvertently Fail to Benefit the Environment. J. Green Build. 2006, 1, 152-165. [CrossRef]

23. Kensek, K. Visual Programming for Building Information Modeling: Energy and Shading Analysis Case Studies. J. Green Build. 2015, 10, 28-43. [CrossRef]

24. MacDougall, C. Natural Building Materials in Mainstream Construction: Lessons from the U. K. J. Green Build. 2008, 3, 1-14. [CrossRef]

25. Schroepfer, T.; Hee, L. Emerging Forms of Sustainable Urbanism: Case Studies of Vauban Freiburg and solar City Linz. J. Green Build. 2008, 3, 65-76. [CrossRef]

26. Tinker, A.; Kreuter, U.; Burt, R.; Bame, S. Green Construction: Contractor Motivation and Trends in Austin, Texas. J. Green Build. 2006, 1, 118-134. [CrossRef]

27. Yau, Y. Willingness to Pay and Preferences for Green Housing Attributes in Hong Kong. J. Green Build. 2012, 7, 137-152. [CrossRef]

28. Coar, M.; Sarreshtehdari, A.; Garlock, M.; Khorasani, N.E. Methodology and challenges of fire following earthquake analysis: An urban community study considering water and transportation networks. Nat. Hazards 2021, 109, 1-31. [CrossRef]

29. Lu, X.; Zeng, X.; Xu, Z.; Guan, H. Physics-based Simulation and High-fidelity Visualization of Fire Following Earthquake Considering Building Seismic Damage. J. Earthq. Eng. 2017, 23, 1173-1193. [CrossRef]

30. Ji, T.; Wei, H.-H.; Shohet, I.M.; Xiong, F. Risk-based resilience concentration assessment of community to seismic hazards. Nat. Hazards 2021, 108, 1731-1751. [CrossRef]

31. Liu, X.; Li, S.; Xu, X.; Luo, J. Integrated natural disasters urban resilience evaluation: The case of China. Nat. Hazards 2021, 107, 2105-2122. [CrossRef]

32. Sun, W.; Hou, Y.; Guo, L. Big data revealed relationship between air pollution and manufacturing industry in China. Nat. Hazards 2021, 107, 2533-2553. [CrossRef]

33. Zheng, Y.; Xie, Y.; Long, X. A comprehensive review of Bayesian statistics in natural hazards engineering. Nat. Hazards 2021, 108, 63-91. [CrossRef]

34. Kendra, J.; Clay, L.; Gill, K.; Trivedi, J.; Marlowe, V.; Aguirre, B.; Nigg, J.; Trainor, J.; Carbone, E.; Links, J. Community Resilience: Toward a Framework for an Integrated, Interdisciplinary Model of Disaster. Nat. Hazards Rev. 2021, 22, 04021049. [CrossRef] 
35. Fuchs, S.; Keiler, M.; Glade, T. Editorial to the special issue on resilience and vulnerability assessments in natural hazard and risk analysis. Nat. Hazards Earth Syst. Sci. 2017, 17, 1203-1206. [CrossRef]

36. Fuchs, S.; Keiler, M.; Ortlepp, R.; Schinke, R.; Papathoma-Köhle, M. Recent advances in vulnerability assessment for the built environment exposed to torrential hazards: Challenges and the way forward. J. Hydrol. 2019, 575, 587-595. [CrossRef]

37. Papathoma-Köhle, M.; Thaler, T.; Fuchs, S. An institutional approach to vulnerability: Evidence from natural hazard management in Europe. Environ. Res. Lett. 2021, 16, 044056. [CrossRef]

38. Birkmann, J.; Jamshed, A.; McMillan, J.M.; Feldmeyer, D.; Totin, E.; Solecki, W.; Ibrahim, Z.Z.; Roberts, D.; Kerr, R.B.; Poertner, H.-O.; et al. Understanding human vulnerability to climate change: A global perspective on index validation for adaptation planning. Sci. Total Environ. 2021, 803, 150065. [CrossRef]

39. Mazzorana, B.; Comiti, F.; Scherer, C.; Fuchs, S. Developing consistent scenarios to assess flood hazards in mountain streams. J. Environ. Manag. 2012, 94, 112-124. [CrossRef] [PubMed]

40. Kappes, M.S.; Keiler, M.; von Elverfeldt, K.; Glade, T. Challenges of analyzing multi-hazard risk: A review. Nat. Hazards 2012, 64, 1925-1958. [CrossRef]

41. Navarro, O.; Restrepo-Ochoa, D.; Muñoz-Duque, L.A.; Zapa-Perez, K.; Ameline, A.; Mercier, D.; Fleury-Bahi, G. Determinants of coping strategies in two types of natural hazards: Flash floods and costal flooding. Int. J. Disaster Risk Reduct. 2020, $46,101514$. [CrossRef]

42. Janizadeh, S.; Pal, S.C.; Saha, A.; Chowdhuri, I.; Ahmadi, K.; Mirzaei, S.; Mosavi, A.H.; Tiefenbacher, J.P. Mapping the spatial and temporal variability of flood hazard affected by climate and land-use changes in the future. J. Environ. Manag. 2021, $298,113551$. [CrossRef]

43. Monge, J.J.; McDonald, N.; McDonald, G.W. A review of graphical methods to map the natural hazard-to-wellbeing risk chain in a socio-ecological system. Sci. Total Environ. 2021, 803, 149947. [CrossRef] [PubMed]

44. Berlemann, M.; Eurich, M. Natural hazard risk and life satisfaction-Empirical evidence for hurricanes. Ecol. Econ. 2021, 190, 107194. [CrossRef]

45. Stritih, A.; Bebi, P.; Rossi, C.; Grêt-Regamey, A. Addressing disturbance risk to mountain forest ecosystem services. J. Environ. Manag. 2021, 296, 113188. [CrossRef] [PubMed]

46. Yabe, T.; Rao, P.S.C.; Ukkusuri, S.V. Resilience of Interdependent Urban Socio-Physical Systems using Large-Scale Mobility Data: Modeling Recovery Dynamics. Sustain. Cities Soc. 2021, 75, 103237. [CrossRef]

47. Ferrario, M.F. Landslides triggered by multiple earthquakes: Insights from the 2018 Lombok (Indonesia) events. Nat. Hazards 2019, 98, 575-592. [CrossRef]

48. Ma, S.; Xu, C. Assessment of co-seismic landslide hazard using the Newmark model and statistical analyses: A case study of the 2013 Lushan, China, Mw6.6 earthquake. Nat. Hazards 2018, 96, 389-412. [CrossRef]

49. Huang, X.; Jin, H. An earthquake casualty prediction model based on modified partial Gaussian curve. Nat. Hazards 2018, 94, 999-1021. [CrossRef]

50. Gao, D.; Wang, K.; Insua, T.L.; Sypus, M.; Riedel, M.; Sun, T. Defining megathrust tsunami source scenarios for northernmost Cascadia. Nat. Hazards 2018, 94, 445-469. [CrossRef]

51. Anbazhagan, P.; Mog, K.; Rao, K.S.N.; Prabhu, N.S.; Agarwal, A.; Reddy, G.R.; Ghosh, S.; Deb, M.K.; Baruah, S.; Das, S.K. Reconnaissance report on geotechnical effects and structural damage caused by the 3 January 2017 Tripura earthquake, India. Nat. Hazards 2019, 98, 425-450. [CrossRef]

52. Beirlant, J.; Kijko, A.; Reynkens, T.; Einmahl, J.H.J. Estimating the maximum possible earthquake magnitude using extreme value methodology: The Groningen case. Nat. Hazards 2018, 98, 1091-1113. [CrossRef]

53. Sun, L.; Su, G.; Tian, Q.; Qi, W.; Liu, F.; Qi, M.; Li, R. Religious belief and Tibetans' response to earthquake disaster: A case study of the 2010 Ms 7.1 Yushu earthquake, Qinghai Province, China. Nat. Hazards 2019, 99, 141-159. [CrossRef]

54. Zhou, W.; Guo, S.; Deng, X.; Xu, D. Livelihood resilience and strategies of rural residents of earthquake-threatened areas in Sichuan Province, China. Nat. Hazards 2021, 106, 255-275. [CrossRef]

55. Jin, K.P.; Yao, L.K.; Cheng, Q.G.; Xing, A.G. Seismic landslides hazard zoning based on the modified Newmark model: A case study from the Lushan earthquake, China. Nat. Hazards 2019, 99, 493-509. [CrossRef]

56. Pozos-Estrada, A.; Chávez, M.M.; Jaimes, M.; Arnau, O.; Guerrero, H. Damages observed in locations of Oaxaca due to the Tehuantepec Mw8.2 earthquake, Mexico. Nat. Hazards 2019, 97, 623-641. [CrossRef]

57. Cubellis, E.; Luongo, G.; Obrizzo, F.; Sepe, V.; Tammaro, U. Contribution to knowledge regarding the sources of earthquakes on the island of Ischia (Southern Italy). Nat. Hazards 2020, 100, 955-994. [CrossRef]

58. Ma, Z.; Guo, S.; Deng, X.; Xu, D. Community resilience and resident's disaster preparedness: Evidence from China's earthquakestricken areas. Nat. Hazards 2021, 108, 567-591. [CrossRef]

59. Schekotov, A.; Chebrov, D.; Hayakawa, M.; Belyaev, G.; Berseneva, N. Short-term earthquake prediction in Kamchatka using low-frequency magnetic fields. Nat. Hazards 2019, 100, 735-755. [CrossRef]

60. Kumlu, K.B.Y.; Tüdeş, Ş. Determination of earthquake-risky areas in Yalova City Center (Marmara region, Turkey) using GISbased multicriteria decision-making techniques (analytical hierarchy process and technique for order preference by similarity to ideal solution). Nat. Hazards 2019, 96, 999-1018. [CrossRef]

61. Yurdakul, Ö.; Duran, B.; Tunaboyu, O.; Avşar, Ö. Field reconnaissance on seismic performance of RC buildings after the January 24, 2020 Elazığ-Sivrice earthquake. Nat. Hazards 2020, 105, 859-887. [CrossRef] 
62. Zafarani, H.; Jafarian, Y.; Eskandarinejad, A.; Lashgari, A.; Soghrat, M.R.; Sharafi, H.; Afraz-e Haji-Saraei, M. Seismic hazard analysis and local site effect of the 2017 M w 7.3 Sarpol-e Zahab, Iran, earthquake. Nat. Hazards 2020, 103, 1783-1805. [CrossRef]

63. Danatzko, J.M.; Sezen, H.; Chen, Q. Sustainable design and energy consumption analysis for structural components. J. Green Build. 2013, 8, 120-135. [CrossRef]

64. Weerasinghe, G.; Soundararajan, K.; Ruwanpura, J. LEED-PDRI Framework for Pre-project Planning of Sustainable Building Projects. J. Green Build. 2007, 2, 123-143. [CrossRef]

65. Farahani, S.; Tahershamsi, A.; Behnam, B. Earthquake and post-earthquake vulnerability assessment of urban gas pipelines network. Nat. Hazards 2020, 101, 327-347. [CrossRef]

66. Ji, T.; Wei, H.-H.; Sim, T.; Yang, L.E.; Scheffran, J. Disaggregated validation of disaster-resilience indicators using household survey data: A case study of Hong Kong. Sustain. Cities Soc. 2021, 67, 102726. [CrossRef]

67. Valentin, V.; Bogus, S.M. Assessing the link between public opinion and social sustainability in building and infrastructure projects. J. Green Build. 2015, 10, 177-190. [CrossRef]

68. Boake, T.M. The Leap to Zero Carbon and Zero Emissions: Understanding How to Go Beyond Existing Sustainable Design Protocols. J. Green Build. 2008, 3, 64-77. [CrossRef]

69. Eriksen, M.S.H.; Bjarløv, S.P.; Rode, C. Strengthening requirement specification in sustainable procurement-An investigation of challenges. J. Green Build. 2017, 12, 107-122. [CrossRef]

70. Palanisamy, P.; Klotz, L. Delivery process attributes, common to India and the U.S., for more sustainable buildings. J. Green Build. 2011, 6, 146-157. [CrossRef]

71. Omidvar, B.; Eskandari, M.; Peyghaleh, E. Seismic damage to urban areas due to failed buried fuel pipelines case study: Fire following earthquake in the city of Kermanshah, Iran. Nat. Hazards 2013, 67, 169-192. [CrossRef]

72. Horman, M.J.; Riley, D.R.; Lapinski, A.R.; Korkmaz, S.; Pulaski, M.H.; Magent, C.S.; Luo, Y.; Harding, N.; Dahl, P.K. Delivering Green Buildings: Process Improvements for Sustainable Construction. J. Green Build. 2006, 1, 123-140. [CrossRef]

73. Potbhare, V.; Syal, M.; Korkmaz, S. Adoption of Green Building Guidelines in Developing Countries Based on U.S. and India Experiences. J. Green Build. 2009, 4, 158-174. [CrossRef]

74. Roostaie, S.; Kouhirostami, M.; Sam, M.; Kibert, C.J. Resilience coverage of global sustainability assessment frameworks: A systematic review. J. Green Build. 2021, 16, 23-53. [CrossRef]

75. Shaikh, F.U.A.; Hosan, A.; Biswas, W.K. Sustainability assessment of reinforced concrete beam mixes containing recycled aggregates and industrial by-products. J. Green Build. 2020, 15, 95-119. [CrossRef]

76. Suh, M.J.; Pearce, A.R.; Song, Y.; Kwak, Y.H.; Kim, J.I.; Zhang, Y. The Impact of Leed-Energy Star Certified Office Buildings on the Market Value of Adjoining Buildings in New York City. J. Green Build. 2019, 14, 31-52. [CrossRef]

77. Tan, S.B. Measuring community resilience: A critical analysis of a policy-oriented indicator tool. Environ. Sustain. Ind. 2021, $12,100142$.

78. Abdelhady, A.U.; Spence, S.M.; McCormick, J. Risk and fragility assessment of residential wooden buildings subject to hurricane winds. Struct. Saf. 2021, 94, 102137. [CrossRef]

79. Wang, W.; van de Lindt, J.W.; Rosenheim, N.; Cutler, H.; Hartman, B.; Lee, J.S.; Calderon, D. Effect of Residential Building Wind Retrofits on Social and Economic Community-Level Resilience Metrics. J. Infrastruct. Syst. 2021, 27, 04021034. [CrossRef]

80. Her, C.; Sambor, D.J.; Whitney, E.; Wies, R. Novel wind resource assessment and demand flexibility analysis for community resilience: A remote microgrid case study. Renew. Energy 2021, 179, 1472-1486. [CrossRef]

81. Gholizadeh, M. Effects of floods on macroinvertebrate communities in the Zarin Gol River of northern Iran: Implications for water quality monitoring and biological assessment. Ecol. Process. 2021, 10, 1-11. [CrossRef]

82. Nofal, O.M.; van de Lindt, J.W.; Do, T.Q.; Yan, G.; Hamideh, S.; Cox, D.T.; Dietrich, J.C. Methodology for Regional Multihazard Hurricane Damage and Risk Assessment. J. Struct. Eng. 2021, 147, 04021185. [CrossRef]

83. Baca, M.; Schenkman, B.; Hightower, M. Use of Advanced Microgrids to Support Community Resilience. Nat. Hazards Rev. 2021, 22, 05021012. [CrossRef]

84. Chen, Y.; Ji, W. Rapid Damage Assessment Following Natural Disasters through Information Integration. Nat. Hazards Rev. 2021, 22, 04021043. [CrossRef]

85. Kim, J.; Kamari, M.; Lee, S.; Ham, Y. Large-Scale Visual Data-Driven Probabilistic Risk Assessment of Utility Poles Regarding the Vulnerability of Power Distribution Infrastructure Systems. J. Constr. Eng. Manag. 2021, 147, 04021121. [CrossRef]

86. Sim, T.; Han, Z.; Guo, C.; Lau, J.; Yu, J.; Su, G. Disaster preparedness, perceived community resilience, and place of rural villages in northwest China. Nat. Hazards 2021, 108, 907-923. [CrossRef]

87. Bulti, D.T.; Girma, B.; Megento, T.L. Community flood resilience assessment frameworks: A review. SN Appl. Sci. $2019,1,1663$. [CrossRef]

88. He, Z.; Chen, H. An ISM-Based Methodology for Interrelationships of Critical Success Factors for Construction Projects in Ecologically Fragile Regions: Take Korla, China as an Example. Appl. Sci. 2021, 11, 4668. [CrossRef]

89. He, Z.; Chen, H. Critical factors for practicing sustainable construction projects in environmentally fragile regions based on interpretive structural modeling and cross-impact matrix multiplication applied to classification: A case study in China. Sustain. Cities Soc. 2021, 74, 103238. [CrossRef] 
90. Moghayedi, A.; Awuzie, B.; Omotayo, T.; Le Jeune, K.; Massyn, M.; Ekpo, C.; Braune, M.; Byron, P. A Critical Success Factor Framework for Implementing Sustainable Innovative and Affordable Housing: A Systematic Review and Bibliometric Analysis. Buildings 2021, 11, 317. [CrossRef]

91. Dang, P.; Niu, Z.; Gao, S.; Hou, L.; Zhang, G. Critical Factors Influencing the Sustainable Construction Capability in Prefabrication of Chinese Construction Enterprises. Sustainability 2020, 12, 8996. [CrossRef]

92. Olawumi, T.O.; Chan, D.W. Critical success factors for implementing building information modeling and sustainability practices in construction projects: A Delphi survey. Sustain. Dev. 2019, 27, 587-602. [CrossRef]

93. Yu, S.; Malecha, M.; Berke, P. Examining factors influencing plan integration for community resilience in six US coastal cities using Hierarchical Linear Modeling. Landsc. Urban Plan. 2021, 215, 104224. [CrossRef]

94. DiCarlo, M.F.; Berglund, E.Z. Connected communities improve hazard response: An agent-based model of social media behaviors during hurricanes. Sustain. Cities Soc. 2021, 69, 102836. [CrossRef]

95. Wardekker, A. Contrasting the framing of urban climate resilience. Sustain. Cities Soc. 2021, 75, 103258. [CrossRef]

96. Huang, S.; Wang, J.; Fu, Y.; Zuo, W.; Hinkelman, K.; Kaiser, R.M.; He, D.; Vrabie, D. An open-source virtual testbed for a real Net-Zero Energy Community. Sustain. Cities Soc. 2021, 75, 103255. [CrossRef]

97. Esmalian, A.; Dong, S.; Mostafavi, A. Susceptibility curves for humans: Empirical survival models for determining householdlevel disturbances from hazards-induced infrastructure service disruptions. Sustain. Cities Soc. 2020, 66, 102694. [CrossRef]

98. Roberts, F.; Archer, F.; Spencer, C. The potential role of nonprofit organisations in building community resilience to disasters in the context of Victoria, Australia. Int. J. Disaster Risk Reduct. 2021, 65, 102530. [CrossRef]

99. Lin, S.-Y.; El-Tawil, S.; Aguirre, B.E. Computational Simulation of Benefit Fraud and Community Resilience in the Wake of Disaster. Nat. Hazards Rev. 2020, 21, 04020039. [CrossRef]

100. Schulze, S.S.; Fischer, E.C.; Hamideh, S.; Mahmoud, H. Wildfire impacts on schools and hospitals following the 2018 California Camp Fire. Nat. Hazards 2020, 104, 901-925. [CrossRef]

101. Zou, Y.; Stock, A.; Davidson, R.; Nozick, L.; Trainor, J.; Kruse, J. Perceived attributes of hurricane-related retrofits and their effect on household adoption. Nat. Hazards 2020, 104, 201-224. [CrossRef]

102. Fraser, T.; Aldrich, D.P.; Small, A. Connecting Social Capital and Vulnerability: Citation Network Analysis of Disaster Studies. Nat. Hazards Rev. 2021, 22, 04021016. [CrossRef]

103. Rakotosamimanana, S.; Rakotoarimanana, F.J.; Raharimanga, V.; Taglioni, F.; Ramamonjisoa, J.; Randremanana, R.V.; Rajerison, M.; Rakotomanana, F. Additional file 1 of Influence of Sociospatial determinants on knowledge, attitudes and practices related to the plague in a population living in endemic areas in the central highlands, Madagascar. BMC Public Health 2021, $21,1-11$. [CrossRef]

104. Khalafzai, M.-A.K.; McGee, T.K.; Parlee, B. Spring flooding and recurring evacuations of Kashechewan First Nation, northern Ontario, Canada. Int. J. Disaster Risk Reduct. 2021, 63, 102443. [CrossRef]

105. Page-Tan, C. An analysis of social media use and neighbor-assisted debris removal in Houston following Hurricane Harvey. Int. J. Disaster Risk Reduct. 2021, 63, 102450. [CrossRef]

106. Uddin, M.S.; Haque, C.E.; Khan, M.N.; Doberstein, B.; Cox, R.S. Disasters threaten livelihoods, and people cope, adapt and make transformational changes: Community resilience and livelihoods reconstruction in coastal communities of Bangladesh. Int. J. Disaster Risk Reduct. 2021, 63, 102444. [CrossRef]

107. Bernardini, G.; Finizio, F.; Postacchini, M.; Quagliarini, E. Assessing the flood risk to evacuees in outdoor built environments and relative risk reduction strategies. Int. J. Disaster Risk Reduct. 2021, 64, 102493. [CrossRef]

108. Choudhury, M.-U.; Haque, C.E.; Doberstein, B. Adaptive governance and community resilience to cyclones in coastal Bangladesh: Addressing the problem of fit, social learning, and institutional collaboration. Environ. Sci. Policy 2021, 124, 580-592. [CrossRef]

109. Mohibbullah, M.; Gain, A.K.; Ahsan, N. Examining local institutional networks for sustainable disaster management: Empirical evidence from the South-West coastal areas in Bangladesh. Environ. Sci. Policy 2021, 124, 433-440. [CrossRef]

110. Ramezani, R.; Farshchin, A. Urban Resilience and Its Relationship with Urban Poverty. J. Urban Plan. Dev. 2021, $147,05021042$. [CrossRef]

111. Hestad, D.; Tàbara, J.D.; Thornton, T.F. The role of sustainability-oriented hybrid organisations in the development of transformative capacities: The case of Barcelona. Cities 2021, 119, 103365. [CrossRef]

112. Fazey, I.; Carmen, E.; Ross, H.; Rao-Williams, J.; Hodgson, A.; Searle, B.A.; AlWaer, H.; Kenter, J.O.; Knox, K.; Butler, J.R.A.; et al. Social dynamics of community resilience building in the face of climate change: The case of three Scottish communities. Sustain. Sci. 2021, 16, 1731-1747. [CrossRef]

113. Tshimanga, R.M.; Lutonadio, G.S.K.; Kabujenda, N.K.; Sondi, C.M.; Mihaha, E.T.N.; Ngandu, J.F.K.; Nkaba, L.N.; Sankania, G.M.; Beya, J.T.; Kombayi, A.M.; et al. An integrated information system of climate-watermigrations-conflicts nexus in the Congo basin. Sustainability 2021, 13, 9323. [CrossRef]

114. Ilie, M.; Ilie, G. The traditional wooden gates of maramure (Romania) as a part of the place legitimization processes. Transylv. Rev. 2021, 30, 83-98. [CrossRef]

115. Bilau, A.A.; Witt, E.; Lill, I. Analysis of Measures for Managing Issues in Post-Disaster Housing Reconstruction. Buildings 2017, 7, 29. [CrossRef]

116. Bae, J.-W.; Kim, Y.-W. Sustainable Value on Construction Projects and Lean Construction. J. Green Build. $2008,3,156-167$. [CrossRef] 
117. Keysar, E.; Pearce, A.R. Decision Support Tools for Green Building: Facilitating Selection among New Adopters on Public Sector Projects. J. Green Build. 2007, 2, 153-171. [CrossRef]

118. Ariaratnam, S.T.; Sihabuddin, S.S. Comparison of Emitted Emissions between Trenchless Pipe Replacement and Open Cut Utility Construction. J. Green Build. 2009, 4, 126-140. [CrossRef]

119. Burroughs, S. Recommendations for the Selection, Stabilization, and Compaction of Soil for Rammed Earth Wall Construction. J. Green Build. 2010, 5, 101-114. [CrossRef]

120. De Luca, P.; Carbone, I.; Nagy, J.B. Green Building Materials: A Review of State of the Art Studies of Innovative Materials. J. Green Build. 2017, 12, 141-161. [CrossRef]

121. Mulligan, T.; Mollaoğlu-Korkmaz, S.; Cotner, R.; Goldsberry, A.D. Public policy and impacts on adoption of sustainable built environments: Learning from the constuction industry playmakers. J. Green Build. 2014, 9, 182-202. [CrossRef]

122. Cheng, B.; Li, J.; Tam, V.W.Y.; Yang, M.; Chen, D. A BIM-LCA Approach for Estimating the Greenhouse Gas Emissions of Large-Scale Public Buildings: A Case Study. Sustainability 2020, 12, 685. [CrossRef]

123. Xiao, L.; Lo, S.; Liu, J.; Zhou, J.; Li, Q. Nonlinear and synergistic effects of TOD on urban vibrancy: Applying local explanations for gradient boosting decision tree. Sustain. Cities Soc. 2021, 72, 103063. [CrossRef]

124. Van De Lindt, J.W.; Peacock, W.G.; Mitrani-Reiser, J.; Rosenheim, N.; Deniz, D.; Dillard, M.; Tomiczek, T.; Koliou, M.; Graettinger, A.; Crawford, P.S.; et al. Community Resilience-Focused Technical Investigation of the 2016 Lumberton, North Carolina, Flood: An Interdisciplinary Approach. Nat. Hazards Rev. 2020, 21, 04020029. [CrossRef]

125. Wu, W.-N. Disaster-Resistant Community: An examination of developmental differences. Nat. Hazards 2020, 101, 125-142. [CrossRef]

126. Sutton, S.A.; Paton, D.; Buergelt, P.; Sagala, S.; Meilianda, E. Nandong smong and tsunami lullabies: Song and music as an effective communication tool in disaster risk reduction. Int. J. Disaster Risk Reduct. 2021, 65, 102527. [CrossRef]

127. Rendon, C.; Osman, K.K.; Faust, K.M. Path towards community resilience: Examining stakeholders' coordination at the intersection of the built, natural, and social systems. Sustain. Cities Soc. 2021, 68, 102774. [CrossRef]

128. Qiang, Y.; Huang, Q.; Xu, J. Observing community resilience from space: Using nighttime lights to model economic disturbance and recovery pattern in natural disaster. Sustain. Cities Soc. 2020, 57, 102115. [CrossRef]

129. Yang, Y.; Ng, S.T.; Zhou, S.; Xu, F.J.; Li, D.; Li, H. A federated pre-event community resilience approach for assessing physical and social sub-systems: An extreme rainfall case in Hong Kong. Sustain. Cities Soc. 2019, 52, 101859. [CrossRef]

130. Jafari, M.; Alipour, A. Review of approaches, opportunities, and future directions for improving aerodynamics of tall buildings with smart facades. Sustain. Cities Soc. 2021, 72, 102979. [CrossRef]

131. Davis, C.A. Understanding Functionality and Operability for Infrastructure System Resilience. Nat. Hazards Rev. 2021, 22, 06020005. [CrossRef]

132. Sediek, O.A.; El-Tawil, S.; McCormick, J. Dynamic Modeling of In-Event Interdependencies in Community Resilience. Nat. Hazards Rev. 2020, 21, 04020041. [CrossRef]

133. Nozhati, S.; Ellingwood, B.R.; Mahmoud, H. Understanding Community Resilience from a PRA Perspective Using Binary Decision Diagrams. Risk Anal. 2019, 39, 2127-2142. [CrossRef]

134. Jia, Y.; Sasani, M. Modeling Joint Probability of Wind and Flood Hazards in Boston. Nat. Hazards Rev. 2021, $22,04021047$. [CrossRef]

135. Miller, W.; Machard, A.; Bozonnet, E.; Yoon, N.; Qi, D.; Zhang, C.; Liu, A.; Sengupta, A.; Akander, J.; Hayati, A.; et al. Conceptualising a resilient cooling system: A socio-technical approach. City Environ. Interact. 2021, 11, 100065. [CrossRef]

136. Chen, Q.; Kleinman, L.; Dial, A. Energy performance of campus leed ${ }^{\circledR}$ buildings: Implications for green building and energy policy. J. Green Build. 2015, 10, 137-160. [CrossRef]

137. Chen, X.; Lu, W.; Xue, F.; Xu, J. A cost-benefit analysis of green buildings with respect to construction waste minimization using big data in Hong Kong. J. Green Build. 2018, 13, 61-76. [CrossRef]

138. Budowle, R.; Krszjzaniek, E.; Taylor, C. Students as Change Agents for Community-University Sustainability Transition Partnerships. Sustainability 2021, 13, 6036. [CrossRef]

139. Leckey, E.H.; Littrell, M.K.; Okochi, C.; González-Bascó, I.; Gold, A.; Rosales-Collins, S. Exploring local environmental change through filmmaking: The Lentes en Cambio Climático program. J. Environ. Educ. 2021, 52, 207-222. [CrossRef]

140. Surya, B.; Suriani, S.; Menne, F.; Abubakar, H.; Idris, M.; Rasyidi, E.; Remmang, H. Community Empowerment and Utilization of Renewable Energy: Entrepreneurial Perspective for Community Resilience Based on Sustainable Management of Slum Settlements in Makassar City, Indonesia. Sustainability 2021, 13, 3178. [CrossRef]

141. Pacheco, E.M.; Bisaga, I.; Oktari, R.S.; Parikh, P.; Joffe, H. Integrating psychosocial and WASH school interventions to build disaster resilience. Int. J. Disaster Risk Reduct. 2021, 65, 102520. [CrossRef]

142. Floetgen, R.; Strauss, J.; Weking, J.; Hein, A.; Urmetzer, F.; Böhm, M.; Krcmar, H. Introducing platform ecosystem resilience: Leveraging mobility platforms and their ecosystems for the new normal during COVID-19. Eur. J. Inf. Syst. 2021, 30, 304-321. [CrossRef]

143. Zamuda, C.D.; Ressler, A. Federal adaptation and mitigation programs supporting Community investment in electricity resilience to extreme weather. Electr. J. 2020, 33, 106825. [CrossRef]

144. Zhang, W.; Valencia, A.; Gu, L.; Zheng, Q.P.; Chang, N.-B. Integrating emerging and existing renewable energy technologies into a community-scale microgrid in an energy-water nexus for resilience improvement. Appl. Energy 2020, 279, 115716. [CrossRef] 
145. Bukar, U.A.; Jabar, M.A.; Sidi, F.; Nor, R.N.H.B.; Abdullah, S.; Othman, M. Crisis Informatics in the Context of Social Media Crisis Communication: Theoretical Models, Taxonomy, and Open Issues. IEEE Access 2020, 8, 185842-185869. [CrossRef]

146. Kaupper, T.; Mendes, L.W.; Harnisz, M.; Krause, S.M.B.; Horn, M.A.; Ho, A. Recovery of Methanotrophic Activity Is Not Reflected in the Methane-Driven Interaction Network after Peat Mining. Appl. Environ. Microbiol. 2021, 87. [CrossRef]

147. Masindi, V.; Chatzisymeon, E.; Kortidis, I.; Foteinis, S. Assessing the sustainability of acid mine drainage (AMD) treatment in South Africa. Sci. Total Environ. 2018, 635, 793-802. [CrossRef]

148. Randolph, R.; Chacko, S.; Morsch, G. Disaster Medicine: Public Health Threats Associated with Disasters. FP Essent 2019, 487, 11-16.

149. Roemer, K.F.; Haggerty, J.H. Coal communities and the U.S. energy transition: A policy corridors assessment. Energy Policy 2021, 151, 112112. [CrossRef]

150. Yi, C.; Jackson, N. A review of measuring ecosystem resilience to disturbance. Environ. Res. Lett. 2021, 16, 053008. [CrossRef]

151. Lin, H.; Wang, Q.; Zhou, J.; Wang, D.; Men, Y.; Bai, Y.; Qu, J. Recovery trajectories and community resilience of biofilms in receiving rivers after wastewater treatment plant upgrade. Environ. Res. 2021, 199, 111349. [CrossRef]

152. Moura, A.; Centurion, V.; Okada, D.; Motteran, F.; Delforno, T.; Oliveira, V.; Varesche, M. Laundry wastewater and domestic sewage pilot-scale anaerobic treatment: Microbial community resilience regarding sulfide production. J. Environ. Manag. 2019, 251, 109495. [CrossRef]

153. Satty, T. Decisions with the Analytic Network Process (ANP); University of Pittsburgh (USA), ISAHP: Pittsburgh, PA, USA, 1996; Volume 96.

154. Wu, Y.; Zhang, B.; Xu, C.; Li, L. Site selection decision framework using fuzzy ANP-VIKOR for large commercial rooftop PV system based on sustainability perspective. Sustain. Cities Soc. 2018, 40, 454-470. [CrossRef]

155. Mahdiyar, A.; Tabatabaee, S.; Durdyev, S.; Ismail, S.; Abdullah, A.; Rani, W.N.M.W.M. A prototype decision support system for green roof type selection: A cybernetic fuzzy ANP method. Sustain. Cities Soc. 2019, 48, 101532. [CrossRef]

156. Ghosh, S.; Das Chatterjee, N.; Dinda, S. Urban ecological security assessment and forecasting using integrated DEMATEL-ANP and CA-Markov models: A case study on Kolkata Metropolitan Area, India. Sustain. Cities Soc. 2021, 68, 102773. [CrossRef]

157. Rad, T.G.; Sadeghi-Niaraki, A.; Abbasi, A.; Choi, S.-M. A methodological framework for assessment of ubiquitous cities using ANP and DEMATEL methods. Sustain. Cities Soc. 2018, 37, 608-618. [CrossRef]

158. Chang, D.-Y. Applications of the extent analysis method on fuzzy AHP. Eur. J. Oper. Res. 1996, 95, 649-655. [CrossRef]

159. Ghodsypour, S.H.; O'Brien, C. A decision support system for supplier selection using an integrated analytic hierarchy process and linear programming. Int. J. Prod. Econ. 1998, 56-57, 199-212. [CrossRef]

160. Vaidya, O.S.; Kumar, S. Analytic hierarchy process: An overview of applications. Eur. J. Oper. Res. 2006, 169, 1-29. [CrossRef]

161. Chen, H.; Li, H.; Wang, Y.; Cheng, B. A Comprehensive Assessment Approach for Water-Soil Environmental Risk during Railway Construction in Ecological Fragile Region Based on AHP and MEA. Sustainability 2020, 12, 7910. [CrossRef]

162. Pohekar, S.; Ramachandran, M. Application of multi-criteria decision making to sustainable energy planning-A review. Renew. Sustain. Energy Rev. 2004, 8, 365-381. [CrossRef]

163. Rezaei, J. Best-worst multi-criteria decision-making method. Omega 2015, 53, 49-57. [CrossRef]

164. Tzeng, G.-H.; Chiang, C.-H.; Li, C. Evaluating intertwined effects in e-learning programs: A novel hybrid MCDM model based on factor analysis and DEMATEL. Expert Syst. Appl. 2007, 32, 1028-1044. [CrossRef]

165. Opricovic, S.; Tzeng, G.-H. Compromise solution by MCDM methods: A comparative analysis of VIKOR and TOPSIS. Eur. J. Oper. Res. 2004, 156, 445-455. [CrossRef]

166. Sayadi, M.K.; Heydari, M.; Shahanaghi, K. Extension of VIKOR method for decision making problem with interval numbers. Appl. Math. Model. 2009, 33, 2257-2262. [CrossRef]

167. Xu, X. The SIR method: A superiority and inferiority ranking method for multiple criteria decision making. Eur. J. Oper. Res. 2001, 131, 587-602. [CrossRef]

168. Wang, X.; Triantaphyllou, E. Ranking irregularities when evaluating alternatives by using some ELECTRE methods. Omega 2008, 36, 45-63. [CrossRef]

169. Figueira, J.R.; Mousseau, V.; Roy, B. ELECTRE methods. In Multiple Criteria Decision Analysis; Springer: New York, NY, USA, 2016; pp. $155-185$.

170. Guitouni, A.; Martel, J.-M. Tentative guidelines to help choosing an appropriate MCDA method. Eur. J. Oper. Res. 1998, 109, 501-521. [CrossRef]

171. Chang, Y.-H.; Yeh, C.-H. A new method selection approach for fuzzy group multicriteria decision making. Appl. Soft Comput. 2013, 13, 2179-2187. [CrossRef]

172. Zcan, T.; Çelebi, N.; Esnaf, Ş. Comparative analysis of multi-criteria decision making methodologies and implementation of a warehouse location selection problem. Expert Sys. Appl. 2011, 38, 9773-9779.

173. Saaty, T.L.; Ergu, D. When is a Decision-Making Method Trustworthy? Criteria for Evaluating Multi-Criteria Decision-Making Methods. Int. J. Inf. Technol. Decis. Mak. 2015, 14, 1171-1187. [CrossRef]

174. Zanakis, S.H.; Solomon, A.; Wishart, N.; Dublish, S. Multi-attribute decision making: A simulation comparison of select methods. Eur. J. Oper. Res. 1998, 107, 507-529. [CrossRef]

175. Kornyshova, E.; Salinesi, C. MCDM techniques selection approaches: State of the art. In Proceedings of the 2007 IEEE Symposium on Computational Intelligence in Multi-Criteria Decision-Making, Honolulu, HI, USA, 1-5 April 2007; pp. $22-29$. 
176. Li, Y.; Thomas, M.A. A Multiple Criteria Decision Analysis (MCDA) software selection framework. In Proceedings of the 2014 47th Hawaii International Conference on System Sciences, Waikoloa, HI, USA, 6-9 January 2014; pp. 1084-1094.

177. Kolios, A.; Mytilinou, V.; Lozano-Minguez, E.; Salonitis, K. A Comparative Study of Multiple-Criteria Decision-Making Methods under Stochastic Inputs. Energies 2016, 9, 566. [CrossRef]

178. Sałabun, W.; Wątróbski, J.; Shekhovtsov, A. Are MCDA Methods Benchmarkable? A Comparative Study of TOPSIS, VIKOR, COPRAS, and PROMETHEE II Methods. Symmetry 2020, 12, 1549. [CrossRef]

179. Wątróbski, J.; Jankowski, J.; Ziemba, P.; Karczmarczyk, A.; Zioło, M. Generalised framework for multi-criteria method selection. Omega 2018, 86, 107-124. [CrossRef]

180. Brans, J.; Vincke, P.; Mareschal, B. How to select and how to rank projects: The Promethee method. Eur. J. Oper. Res. 1986, 24, 228-238. [CrossRef]

181. Cheng, B.; Wang, L.; Huang, J.; Shi, X.; Hu, X.; Chen, H. A Computing Model for Quantifying the Value of Structural Health Monitoring Information in Bridge Engineering. Math. Probl. Eng. 2020, 2020, 8260909. [CrossRef]

182. Cheng, B.; Wei, Y.; Zhang, W.; Zhou, X.; Chen, H.; Huang, L.; Huang, J.; Kang, X. Evolutionary Game Simulation on Government Incentive Strategies of Prefabricated Construction: A System Dynamics Approach. Complexity 2020, 2020, 8854609. [CrossRef]

183. Cheba, K.; Kiba-Janiak, M.; Baraniecka, A.; Kołakowski, T. Impact of external factors on e-commerce market in cities and its implications on environment. Sustain. Cities Soc. 2021, 72, 103032. [CrossRef]

184. Chen, L.; Pan, W. BIM-aided variable fuzzy multi-criteria decision making of low-carbon building measures selection Sustain. Cities Soc. 2016, 27, 222-232. [CrossRef]

185. Wu, Y.; Wang, Y.; Chen, K.; Xu, C.; Li, L. Social sustainability assessment of small hydropower with hesitant PROMETHEE method. Sustain. Cities Soc. 2017, 35, 522-537. [CrossRef]

186. Palczewski, K.; Sałabun, W. Influence of various normalization methods in PROMETHEE II: An empirical study on the selection of the airport location. Procedia Comput. Sci. 2019, 159, 2051-2060. [CrossRef]

187. Zięba, Z.; Dąbrowska, J.; Marschalko, M.; Pinto, J.; Mrówczyńska, M.; Leśniak, A.; Petrovski, A.; Kazak, J.K. Built Environment Challenges Due to Climate Change. IOP Conf. Ser. Earth Environ. Sci. 2020, 609. [CrossRef]

188. Bouwer, L.M. Observed and projected impacts from extreme weather events: Implications for loss and damage. In Loss and Damage from Climate Change; Springer: Cham, Switzerland, 2019; pp. 63-82. 